\title{
Expression of Neuron-Specific Tubulin Defines a Novel Population in the Proliferative Layers of the Developing Telencephalon
}

\author{
João R. L. Menezes and Marla B. Luskin \\ Department of Anatomy and Cell Biology, Emory University School of Medicine, Atlanta, Georgia 30322
}

We have used a monoclonal antibody against the neuronspecific class III $\beta$-tubulin (TuJ1; Lee et al., 1990b) to study the distribution and morphology of immature neurons in the proliferative ventricular and subventricular zones of the developing telencephalon. Mouse brains from embryonic day 12 (E 12) to postnatal day 5 (P5) were fixed either with a noncross-linking agent, HistoChoice, or with $4 \%$ paraformaldehyde, and processed for TuJ1 immunohistochemistry.

TuJ1 immunoreactivity first appeared in the proliferative zones of the developing cerebral cortex at E13-E14 as the cortical plate was emerging. After E14, tangentially oriented TuJ1-positive cells were abundant at the interface between the ventricular and subventricular zones. This tangential pattern was less conspicuous in the developing striatum. Within the cortical and striatal ventricular zone TuJ1-positive cells were less numerous and displayed a variety of orientations and morphologies. Postnatally, after the period of neurogenesis has ended, TuJ1 immunoreactivity continued to increase in the subventricular zone and remained high until the last developmental stage examined (P5). Anti-MAP2, another neuron-specific marker, never labeled the cells of the ventricular and subventricular zones, pre- or postnatally. To determine the birthdates of TuJ1-positive cells in the cortical-ventricular and subventricular zones, brains were double labeled with TuJ1 and bromodeoxyuridine according to different pulse-chase schedules. TuJ1-positive cells were postmitotic and generated throughout the period of cortical neurogenesis.

Collectively, the results suggest that TuJ1 immunoreactivity distinguishes two neuronal populations: those that remain for an indefinite period of time in the proliferative zones, and those that leave the proliferative zones soon after being generated. Although the fate of the TuJ1-positive cells that reside in the proliferative zones remains unclear, their tangentially aligned orientation and their distribution suggest that they migrate independent of radial glial fibers.

[Key words: class III $\beta$-tubulin, developing cerebral cortex,

\footnotetext{
Received Aug. 31, 1993; revised Jan. 25, 1994; accepted Mar. 9, 1994.

We thank Drs. A. Frankfurter and R. Vallee for generously supplying the primary antibodies TuJ 1 and MAP2-3, respectively; Dr. G. Caminier and the personnel of Amresco Inc. for helpful advice with the use of HistoChoice; and Alice Schmid for valuable comments on the manuscript. This work was supported by a Biomedical Scholars Award from the Pew Charitable Trusts, a Basil O' Connor Starter Scholar Research Award from the March of Dimes Birth Defects Foundation, and a grant from the NIH (NS28380) to M.B.L. J.R.L.M. is a recipient of a fellowstip from CNPy (Brazil).

Correspondence should be addressed to Dr. Marla B. Luskin at the above address.

Copyright (c) 1994 Society for Neuroscience 0270-6474/94/145399-18\$05.00/0
}

immunohistochemistry, neuronal differentiation, neuronal migration, striatum, subventricular zone, telencephalon, ventricular zone]

A prominent feature of the developing telencephalon is the compartmentalization of the proliferating cells into two specialized layers that surround the lateral ventricle, the ventricular zone and the overlying subventricular zone (for review, see McConnell, 1988). It is within the ventricular and subventricular zones that neurons become postmitotic and begin acquiring celltype-specific characteristics. Thereafter, most newly generated neurons migrate to the superficial cellular layers where they complete their differentiation. Nevertheless, the early steps of this differentiation process have remained elusive. Early autoradiographic and electron microscopic studies (Fujita, 1963; Meller et al., 1966; Hinds and Ruffett, 1971; Meller and Tetzlaff, 1975; Shoukimas and Hinds, 1978) characterized the ventricular zone as a homogeneous population of asynchronously proliferating cells. To the contrary, in recent years it has been shown that by the onset of cortical neurogenesis distinct glial and neuronal progenitor cells are present within the ventricular zone (Schmechel and Rakic, 1979; Levitt et al., 1981, 1983; Luskin et al., 1988, 1993), and that the first appearance of radial glia is an even earlier event (Gressens et al., 1992). However, little is known about the emergence of postmitotic neurons in the proliferative zones due to the lack of reliable markers expressed during early neuronal development. To identify definitively the presence of neurons within the proliferative zones, we have used a marker known to be expressed soon after neurons exit the cell cycle.

Clues to the presence of neurons within the proliferative zones were derived by examining the expression of other cell-typespecific markers. For instance, cell staining by neuron-specific markers has been detected in the proliferative zones (Tapscott et al., 1981; Schmechel and Marangos, 1983; Bennett and DiLullo, 1985a,b; Chun and Shatz, 1989; Cobas et al., 1991), but this has always been associated with a subpopulation, and does not account for all the neurons being generated at one time (see, e.g., Bennet and DiLullo, 1985a). Furthermore, the expression of neuronal markers is generally associated with morphological differentiation (Carden et al., 1987), frequently manifested after neurons have completed their migration (Miller, 1988; Tohyama et al., 1991). Moreover, certain molecules, such as the neuron-specific enolase (NSE) and the microtubule-associated protein 2 (MAP2), may not be reliable markers since their expression may vary among neurons (Schmechel and Marangos, 1983; Hamre et al., 1989; Hendry and Bhandari, 1992; Silverman, 1992). Additional clues to the composition of the 


\begin{tabular}{|c|c|c|c|c|c|c|}
\hline \multirow{2}{*}{$\begin{array}{l}\text { Age of } \\
\text { animal } \\
\text { at fix- } \\
\text { ation }\end{array}$} & \multirow{2}{*}{$\begin{array}{l}\text { Number } \\
\text { of } \\
\text { brains }\end{array}$} & \multicolumn{2}{|c|}{ Fixative $^{\mu}$} & \multicolumn{3}{|c|}{ Antibodies } \\
\hline & & Para & Histo & $\mathrm{TuJ} 1$ & MAP2 & $\mathrm{BrdU}$ \\
\hline E12 & 7 & 5 & 2 & 7 & 4 & - \\
\hline E13 & 6 & 3 & 3 & 6 & 4 & - \\
\hline E14 & 8 & 6 & 2 & 8 & 2 & 4 \\
\hline E15 & 10 & 4 & 6 & 10 & 6 & 7 \\
\hline E16 & 10 & 5 & 5 & 10 & 6 & 6 \\
\hline E17 & 3 & 1 & 2 & 3 & 3 & 1 \\
\hline E19 & 2 & 1 & 1 & 2 & 2 & - \\
\hline E20 & 3 & 1 & 2 & 3 & 2 & - \\
\hline P1 & 1 & 1 & - & 1 & 1 & - \\
\hline P5 & 1 & - & 1 & 1 & 1 & - \\
\hline Adult & 2 & 1 & 1 & 2 & 0 & - \\
\hline
\end{tabular}

${ }^{a}$ Para, 4\% paraformaldehyde; Histo, HistoChoice.

proliferative zones stem from an examination of the candidate neurotransmitters expressed within them during the development of the cerebral cortex (Parnavelas et al., 1988; Chun and Shatz, 1989; Schambra et al., 1989; Van Eden et al., 1989; Hajos et al., 1990; Cobas et al., 1991; Del Rio et al., 1992; Schwartz and Meinecke, 1992; Yan et al., 1992). However, it has not been resolved if the cells that express neurotransmitters in the proliferative zones are a subset of the early-generated subplate neurons (Luskin and Shatz, 1985; Chun and Shatz, 1989) or if they represent expression of neurotransmitters by immature neurons that are still undergoing migration. Furthermore, neurotransmitters are not an exclusive marker of neurons. Glial cells (Chronwall and Wolff, 1980; Van Eden et al., 1989) and perhaps even progenitor cells (Schambra et al., 1989; Ma et al., 1992a,b) have also been shown to contain neurotransmitters. Thus, it has been difficult to distinguish postmitotic neurons while still within the proliferative zones.

In the past, it was generally believed that soon after leaving the cell cycle a neuron would migrate outward to its final destination in the telencephalon along radial glial processes (Rakic, 1972; McConnell, 1988; Misson et al., 1991a,b). Recent studies using lineage tracers have questioned whether all cells departing the tclencephalic ventricular zone migrate radially (Walsh and Cepko, 1992, 1993; Grove et al., 1993; Tan and Breen, 1993). Moreover, studies utilizing organotypic cultures and time-lapse videomicroscopy have presented direct evidence of tangential dispersion of migratory cells within the intermediate zone (O'Rourke et al., 1992) or of cells within the ventricular zone (Fishell et al., 1993). Finally, waiting periods and different migration rates for cohorts of newly postmitotic neurons within the proliferative layers have also been proposed (Altman and Bayer, 1990). Taken together, these experiments suggest that the ventricular and subventricular zones may contain different subsets of migrating neurons displaying a variety of orientations. Here we sought to apply techniques that could better reveal the neurons as soon as they exit the mitotic cycle in the proliferative zones.

To label the neuronal population of the developing telencephalic wall wc have used a monoclonal antibody (TuJ1; Lee et al., 1990a,b) specific for the class III $\beta$-tubulin isotype that is expressed exclusively by neurons (Sullivan, 1988). This antibody has been shown to label postmitotic neurons of the CNS very early, during or immediately after the last mitotic cycle (Lee et al., 1990b), and is clearly found in migrating neurons (Moody et al., 1989; Lee et al., 1990b). Most significantly, this molecule is distributed throughout the neuron (Ferreira and Caceres, 1992) and indiscriminately labels all neurons in the postnatal and mature brain independent of region, activity, or cell-type characteristics (Easter et al., 1993; J. R. L. Menezes and $M$. B. Luskin, unpublished observations).

With the use of this monoclonal antibody we demonstrate the presence of a large population of TuJ1-positive cells, presumably ncurons, within the ventricular and subventricular proliferative zones. These cells display a variety of morphologies and orientations within the proliferative zones, but are particularly prominent at the border between the ventricular and subventricular zones, where they have primarily a tangential orientation. In order to determine the birthdates of the TuJ1-positive cells within the proliferative zones we have combined TuJ1 immunolabeling with the thymidine analog bromodeoxyuridine $(\mathrm{BrdU})$, a cell proliferation marker.

\section{Materials and Methods}

Animals and surgical procedures. Inbred C57BL/6J mice (Jackson Laboratories, $\mathrm{ME}$ ) were mated overnight and checked for vaginal plugs in the morning. A positive vaginal plug was considered the day of conception, embryonic day 0 (E0). Birth usually occurred between E19 and E20. In order to normalize the ages of experimental animals, E20 was considered equivalent to postnatal day 0 ( $\mathrm{P} 0)$.

E12-E16 embryos were removed from the uterus of pregnant females deeply anesthetized with chloral hydrate $(600 \mathrm{mg} / \mathrm{kg})$. The embryonic brains were dissected and left in ice-cold Gey's Balanced Salt Solution (GBSS) supplemented with D-glucose $(6.5 \mathrm{mg} / \mathrm{ml})$ until all had been collected. The brains were then fixed by immersion (18-24 hr) in cold $4 \%$ paraformaldehyde in $0.1 \mathrm{~m}$ phosphate-buffered saline (PBS), $\mathrm{pH} 7.4$, or in warm $\left(25-37^{\circ} \mathrm{C}\right)$ HistoChoice (Amresco, DH). Older embryos, pups, and adults (anesthetized by ether inhalation) were perfused through the heart with cold $4 \%$ paraformaldehyde in PBS or warm HistoChoice for $5-10 \mathrm{~min}$ and postfixed overnight at $4^{\circ} \mathrm{C}$ in the same fixative. HistoChoice is a non-cross-linking, osmotically balanced ( $390 \mathrm{mOsm})$ aqueous fixative that is known to act by inactivation of autolytic enzymes and preservation of tissue integrity. In our hands HistoChoice proved to be a more reliable and sensitive method of fixation for immunohistochemistry than paraformaldehyde, although with some limitations (Menezes and Luskin, unpublished observations).

All brains were cryoprotected, embedded in O.C.T. (Miles Inc., IN), and frozen with liquid nitrogen. They were then cut on a cryostat at $12-20 \mu \mathrm{m}$ in the coronal plane and thaw-mounted to Superfrost microscope slides (Fisher). Table I summarizes the procedures used at each age.

Immunohistochemistry. The primary monoclonal antibodies used in this study and their dilutions were mouse anti- $\beta$-tubulin class III neuron-specific isotype (TuJ1 clone, supplied by A. Frankfurter, University of Virginia, Charlottesville, VA), 1:500; mouse anti- $\beta$-tubulin (Amersham), 1:500; mouse anti-MAP2 (MAP2-3, supplied by R. Vallee, Worcester Foundation, Shrewsbury, MA), 1:20-50; mouse anti-MAP2 (clone HM2, Sigma), 1:500-1000; and rat anti-BrdU (Accurate, NY), 1:100. We also used a polyclonal antibody made in rabbit against the neuron-specific $\beta$-tubulin isotype (supplied by $\mathrm{H}$. Joshi, Emory University, Atlanta, GA), 1:500-1000. The secondary antibodies used and their dilutions were biotinylated or ГITC-conjugated goat anti-mouse IgG (Boehringer-Mannheim), 1:200; FITC-conjugated goat anti-rabbit IgG (Boehringer-Mannheim), 1:200; and rhodamine-conjugated goat anti-rat affinity-purified IgG (Jackson ImmunoResearch Labs, PA), 1:200.

Immunolabeling was revealed by the indirect immunofluorescence procedure or by the avidin-biotin-HRP method (ABC kit, Vector Labs). Briefly, sections were washed in $0.01 \mathrm{~m}$ PBS, $\mathrm{pH} 7.4$, preincubated for $30-40$ min with blocking serum (10\% normal goat serum, $0.01 \%$ Triton

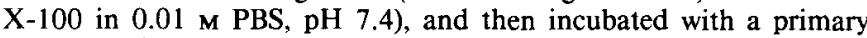
antibody diluted in the same blocking serum. Incubation times were dependent on temperature. At $4^{\circ} \mathrm{C}$ sections were incubated overnight with the primary antibody. If necessary the time could be shortened to $1 \mathrm{hr}$ at $37^{\circ} \mathrm{C}$. Sections were then washed with PBS, and incubated for 
1-2 $\mathrm{hr}$ with the secondary antibody diluted in blocking serum. If a fluorescently tagged secondary was used, sections were washed with PBS and mounted with Slow-Fade (Molecular Probes, OR). The sections were analyzed and photographed immediately or stored at $4^{\circ} \mathrm{C}$ in the dark. If a biotinylated secondary was used, sections were rinsed with PBS and then exposed to the avidin-biotin-HRP complex for $30-40$ $\mathrm{min}$, and the HRP visualized using diaminobenzidine $(1 \mathrm{mg} / \mathrm{ml})$. For control sections the primary antibody was omitted. No labeling was found in the controls except for a weak nonspecific staining sometimes present in the cortical wall, which was particularly prominent over the subplate region (see Fig. 5).

BrdU immunohistochemistry and double-staining procedure. A set of pregnant females received intraperitoneal injections of BrdU (Sigma; $60 \mathrm{mg} / \mathrm{kg}$ dissolved in saline with $0.007 \mathrm{~N} \mathrm{NaOH}$ ), at different times before death (see Results and Table 2). In order to visualize the BrdU incorporation, sections were washed with $0.01 \mathrm{M}$ PBS, pH 7.4, treated with $2 \mathrm{~N} \mathrm{HCl}$ at $37^{\circ} \mathrm{C}$ for $30 \mathrm{~min}$, subsequently rinsed with $0.1 \mathrm{M}$ borate buffer, $\mathrm{pH} 8.3$, twice for $15 \mathrm{~min}$, and washed thoroughly with $0.01 \mathrm{M}$ PBS, pH 7.4, to remove all traces of borate from sections. Sections were then processed according to the immunohistochemical procedure described above.

For visualizing TuJ1 and BrdU labeling in the same section, we applied a sequential immunofluorescence procedure. Briefly, after the denaturing treatment, sections were incubated with $\mathrm{TuJ} 1$ antibody followed by its respective secondary, FITC-conjugated anti-mouse antibody. Instead of coverslipping the slides, sections were washed with PBS, treated for anti-BrdU antibody, and revealed by its specific secondary, rhodamine-conjugated anti-rat antibody. The two fluorescent chromophores could be distinguished easily with appropriate filtcr sets (Leitz Ploempak I2 for FITC, and N2.1 for rhodamine). Three controls were performed: TuJ1 only, followed by anti-rat secondary; anti-BrdU followed by anti-mouse secondary; or, in a third case, primaries omitted altogether. It was shown that the anti-mouse secondary could crossreact with the rat primary antibody. This did not pose a problem if the order of the antibodies remained fixed. No labeling was found in the other controls.

\section{Results}

We studied the expression pattern of neuron-specific class III $\beta$-tubulin during the development of the telencephalic wall of the mouse from embryonic day 12 (E12) to postnatal day 5 (P5), and at adulthood. The analysis was focused on the developing neocortex and in particular its proliferative layers, although comparisons with the adjacent proliferative layers of the developing striatum have been made. The time interval studied encompasses the period of neurogenesis and most of the migratory period for neurons of the developing mouse cerebral cortex (Caviness, 1982). Figure 1 demonstrates the major changes in class III $\beta$-tubulin immunoreactivity of the anterior telencephalic vesicle during the peak of neurogenesis. As neurogenesis progresses the developing cerebral cortex goes from a simple two-layered structure to a complex multilayered wall. Two main conclusions can be readily inferred from the use of the monoclonal antibody TuJ1. First, the distribution and intensity of the TuJ1 immunoreactivity reflect the order of appearance and the degree of maturation of the postmitotic neurons and their processes. Second and unexpectedly, TuJ1 stained very strongly a subset of cells within the proliferative layers. In the forebrain this population exists exclusively in the cortical and striatal proliferative layers (Fig. 1).

Observations with the use of the $\mathrm{TuJ} 1$ monoclonal antibody correlated well with its known neuronal specificity (Lee et al., $1990 \mathrm{a}, \mathrm{b})$. Likewise, the polyclonal anti-class III $\beta$-tubulin also produced similar labeling, although with a higher background (data not shown). On the other hand, a monoclonal antibody against multiple isotypes of $\beta$-tubulin stained all of the developing telencephalic cells, contrasting with the neuronal specificity of TuJ 1 (data not shown).
General pattern of expression of Tull during the development of the telencephalic wall

During cortical development, newly generated postmitotic neurons migrate in an orderly fashion away from the proliferative zones (Boulder Committee, 1970; Caviness, 1982). The preplate, which will later develop into the subplate and marginal zones, constitutes the first contingent of postmitotic neurons to be generated. Correspondingly, TuJ 1 immunoreactivity is first seen in this layer (Figs. 1, 2a,b). Later-generated neurons migrate between the preplate cells and form the cortical plate, which over time will give rise to the cellular layers of the cerebral cortex (Luskin and Shatz, 1985). The progressive change of TuJ1 staining intensity also follows the degree of maturation of these layers: The more mature cells of the marginal zone and subplate layer have a more intense labeling than the cells of the cortical plate, which is composed of younger migrating or postmigratory neurons (Figs. 1, 2a,b). As soon as the cells of the preplate differentiate, a fiber layer appears between the preplate and the ventricular zone, called the intermediate zone. The intermediate zone is the region traversed by the early afferents and efferents to the cerebral cortex (Crandall and Caviness, 1984), and through which immature neurons have to migrate en route to the cortical plate. Both sets of axons are strongly labeled, which gives the intermediate zone a tangentially striated pattern (Figs. 1, 2c,e). Because class III $\beta$-tubulin is evenly distributed within the cell cytoplasm, the overall tissue staining becomes progressively more homogeneous as more and more neurons head for the cortical plate, differentiate, and extend processes.

In the cerebral cortex of neonates the $\mathrm{TuJ} 1$ labeling is almost uniform across the cortical wall, except for the slightly higher intensity of labeling of the subplate and marginal zones. Complete uniformity is achieved by P5. No specific groups or types of neurons were found to be differentially labeled, except for the prominent labeling of cells of the subventricular zone described below. This pattern is maintained without change in the adult, where the whole brain was ubiquitously stained by the $\mathrm{TuJ} 1$ antibody, except for the non-neuronal structures, such as the ependyma, choroid plexus, and pial membranes (not shown).

\section{TuJl immunoreactivity in the ventricular and subventricular zones of the developing cerebral cortex}

Early stages: E12-E13. At the earliest day studied, E12, TuJ1 immunoreactivity was restricted to the preplate (Fig. $2 a$ ). Only occasional staining could be seen in the ventricular zone in the form of radial process-like structures (not shown). Otherwise the ventricular zone was completely devoid of TuJ1-positive cells. The pattern of labeling with $\mathrm{TuJ} 1$ remained the same one day later (Fig. 1). However, at the lateralmost part of the cerebral wall, where a nascent cortical plate (CP) and intermediate zone (IZ) were forming, a low density of TuJ I-positive cells could be detected within the ventricular zone. These cells had a simple morphology and showed no preferred orientation relative to the ventricular surface.

Intermediate stages: E14-E17. Concomitant with the appearance of the cortical plate, $\mathrm{TuJ} 1$-positive cells could be found within the proliferative zones (Fig. $2 b$ ). The emergence of these cells followed the lateral-to-medial gradient of development of the cerebral wall (Smart and McSherry, 1982; Luskin and Shatz, 1985; Fig. 1). These cells increased steadily in numbers in both the ventricular and the subventricular zones until E17 (Fig. $2 e, f)$. The intensity of the staining of $\mathrm{TuJ} 1$-positive cells of the 

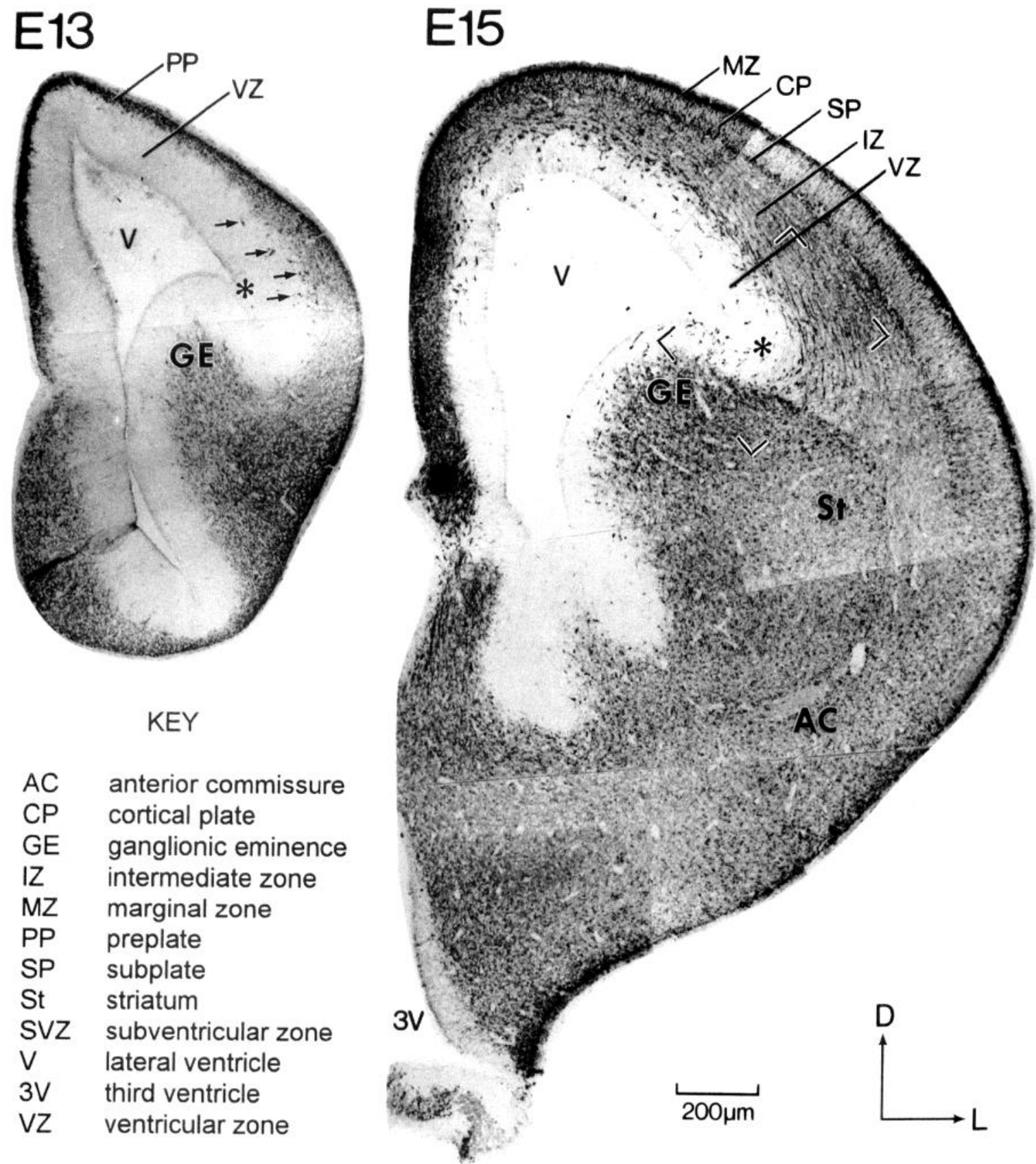

$\begin{array}{ll}\text { AC } & \text { anterior commissure } \\ \mathrm{CP} & \text { cortical plate } \\ \mathrm{GE} & \text { ganglionic eminence } \\ \mathrm{IZ} & \text { intermediate zone } \\ \mathrm{MZ} & \text { marginal zone } \\ \mathrm{PP} & \text { preplate } \\ \mathrm{SP} & \text { subplate } \\ \mathrm{St} & \text { striatum } \\ \mathrm{SVZ} & \text { subventricular zone } \\ \mathrm{V} & \text { lateral ventricle } \\ \text { 3V } & \text { third ventricle } \\ \text { VZ } & \text { ventricular zone }\end{array}$

Figure 1. Low-magnification photomontages of coronal sections from E13 and E15 brains showing the distribution of class III $\beta$-tubulin immunoreactivity in the developing telencephalon. Both sections shown at the same magnification are from approximately the same anteroposterior level (anterior to the interventricular foramen). At E13 the TuJ1 immunoreactivity in the cortical wall is restricted to the preplate (PP), a lamina composed primarily of postmitotic neurons and their processes. There are only a few TuJ1-positive cells (arrows) within the ventricular zone ( $V Z$ ), and they are limited to the lateralmost region of the developing cortical wall, near the caudatopallial angle $(*)$. At E15, by which time a definite cortical plate has formed, TuJ1-positive cells occur throughout the ventricular zone of the developing cerebral cortex. Furthermore, there is an intensely stained band of horizontally oriented TuJ1-immunoreactive cells at the border between the ventricular zone and intermediate zone (IZ). Note that the proliferative zones of the striatum, collectively termed the ganglionic eminence $(G E)$, do not display this band of TuJ1-immunoreactive cells. Instead, the outer portion (subventricular zone) of the ganglionic eminence is evenly stained. Along the ventricular surface of the ganglionic eminence TuJ1-immunoreactive cells tend to accumulate close to the caudatopallial angle $\left({ }^{*}\right)$. The bracketed area is shown at higher magnification in Figure 4. TuJ1 immunoreactivity is absent from the ventricular zones surrounding the ventral apex of the lateral ventricle $(V)$, and the third ventricle $(3 V)$. $D$, dorsal; $L$, lateral.

proliferative zones was much greater than the staining intensity of the cells in the cortical plate. Moreover, the intense staining of the TuJ1-positive cells of the proliferative layers was similar to or even greater than that of the early generated subplate cells.
Such a remarkable difference in the staining strength of the TuJ1-positive cells of the proliferative zones suggests that they have a very early birthdate and/or a unique pattern of expression of the class III $\beta$-tubulin. 


\section{TuJ1}
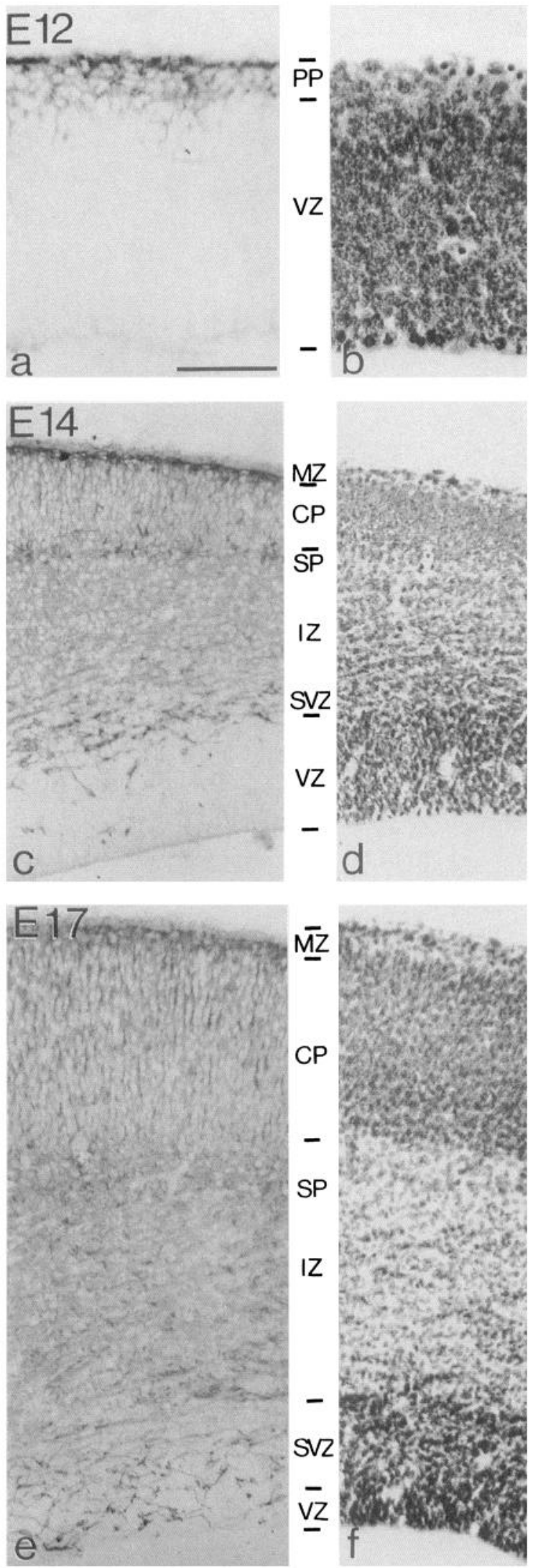

Figure 2. Pattern of class III $\beta$-tubulin expression in the dorsolateral cerebral wall at embryonic ages corresponding to the beginning, middle,
TuJ1-positive cells of the proliferative zones appeared in two distinct patterns. One group was made up of tangentially oriented cells forming a band at the border between the ventricular and subventricular zones (Figs. 1, 2, 3a,c). The vast majority of these cells have a bipolar morphology with a long thick process at one pole and a shorter process at the other (Fig. 3c). Most of the longer processes were directed toward the medial part of the cortex (see also Fig. 4). This morphology is suggestive of cells migrating in the direction of their longer process (Rakic, 1972; O’Rourke et al., 1992).

The second group of cells, found within the ventricular zone, displayed a variety of shapes and orientations that were present in fewer numbers than the cells of the ventricular-subventricular zone border. Occasionally these cells possessed very long processes (Figs. $3 e, 4 d$ ), resembling the GABA-immunoreactive cells previously described to be present within the rodent ventricular zone (Van Eden et al., 1989; Del Rio et al., 1992), and some exhibited a complex morphology, such as that depicted in Figure $3 a$ (long arrows), not at all reminiscent of a migrating cell. However, none of the processes displayed by the TuJ1positive cells could be recognized as an axon. The majority of the TuJ1-positive cells in the ventricular zone had a simple bipolar morphology that could be oriented horizontally like their counterpart along the ventricular-subventricular border, or radially as if migrating toward the outer layers (Fig. $3 d$ ). These different morphologies suggest that the TuJ1-positive cells of the proliferative zones are a mixed population.

It is at the caudatopallial angle where the nonradial orientation of TuJ1-positive cells of the ventricular and subventricular zones is most outstanding (Fig. 4). The caudatopallial angle is the flexure made by the bulging lateral ventricular elevation (ganglionic eminence, GE) against the pallial wall (Smart and Sturrock, 1979). This angle is believed to mark the border between the ventricular zones of the developing neocortex and the striatum (Smart and Sturrock, 1979). It has been shown that neurons generated along the dorsal bank of the caudatopallial angle migrate ventrolaterally toward the lateral isocortex following the guidance of the radial glial fibers (Smart and Sturrock, 1979; Bayer et al., 1991; Misson et al., 1991a). Nevertheless, what is revealed by the TuJ1 immunostaining within the proliferative zones surrounding the angle are not cells directed ventrolaterally, but dorsomedially, perpendicular to the directions of the radial glial processes of this area (Misson et al., 1991a). Frequently, cells with their soma clearly within the ventral bank

and end of cortical neurogenesis. Shown are three pair of adjacent coronal sections processed for TuJ1 immunoreactivity $(a, c, e)$ and hematoxylin-eosin staining $(b, d, f), a$ and $b$, At the beginning of cortical neurogenesis (E12), TuJ1 labeling is restricted to the preplate $(P P)$ and absent from the ventricular zone (VZ). $c$ and $d$, At E14, intensely labeled TuJ1-positive cells are found in low numbers within the ventricular zone and in high numbers at the border between the ventricular zone and subventricular zone (SVZ). The marginal zone $(M Z)$ and the subplate zone $(S P)$ are also heavily labeled, although the cortical plate $(C P)$ sandwiched between them is stained less intensely. Note that this difference in labeling is not a simple reflection of the cell packing density of the layers (see $d$ ). The labeling intensity of the intermediate zone (IZ) is comparable to that of the cortical plate. The intermediate zone has a striated appearance due to the heavily labeled axonal fibers crossing through it. $e$ and $f$, At E17, there is a significant increase in the density of TuJ1-positive cells in both the ventricular and the subventricular zones. The proliferative layers of this section are shown at a higher magnification in Figure 3, $e$ and $f$. Scale bar: $50 \mu \mathrm{m}$ for $a$ and $b, 100$ $\mu \mathrm{m}$ for $c-f$. 

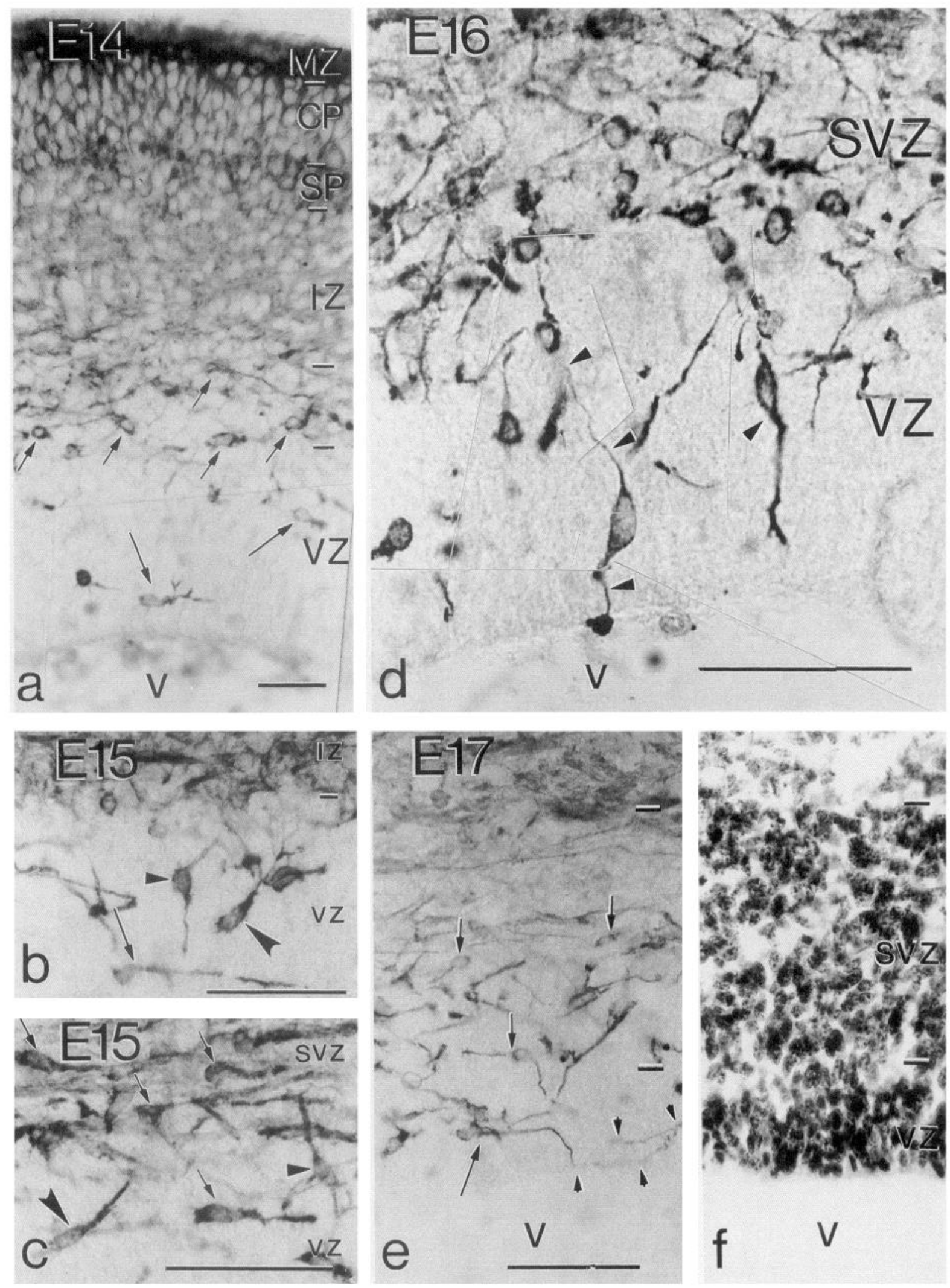

Figure 3. Morphology and orientation of TuJ1-immunoreactive cells in the ventricular and subventricular zones. $a$, Photomontage of a coronal section from the dorsomedial cortical wall at E14. Note the intense labeling of the horizontally oriented cells in the ventricular zone (long arrows) and subventricular zone (short arrows). Cells within the ventricular zone may exhibit a complex morphology, as exemplified by the TuJ1-positive cell located near the ventricular surface. $b$, TuJ1-positive cells in the upper half of the ventricular zone of the medial cerebral wall at E15, displaying radial (small arrowhead), oblique (large arrowhead), and horizontal (arrow) profiles. $c$, Along the dorsolateral cerebral wall of the same section, the TuJ1-positive cells form a band at the border between the ventricular and subventricular zones that is absent in the medial cortex $(b)$. The 
of the caudatopallial angle extended long processes into the cortical germinal zone (Fig. $4 c, d$ ), opposing the local orientation of radial glial cells.

Late stages: E18-P5. Between E17 and E19, as neurogenesis declines and the ventricular zone thins, it progressively looses TuJ1-immunoreactive cells until, by the time of birth, no immunoreactive cell bodies are present (Fig. $5 a, c$ ). This is consistent with the non-neuronal nature of this zone composed of the ependymal cells (Boulder Committee, 1970), the postnatal derivative of the ventricular zone. In contrast, in the subventricular zone, the TuJ1-positive cells increase in number until this layer is almost uniformly stained (Fig. 5). The high cellular density and dense labeling pattern of this layer make it difficult to judge what proportion of cells are TuJ1 negative, if any. Cells are so closely apposed and the $\mathrm{TuJ} 1$ immunoreactivity so abundant that it is also difficult to discriminate between cell body and process labeling. However, at the angle formed by the lateral and dorsal walls of the lateral ventricle some intensely immunoreactive processes emerge from the subventricular zone and cross the ependymal layer terminating at the ventricle surface (Fig. $5 d$, arrowheads). The persistence of $\mathrm{TuJ} 1$-positive cells in such high numbers within the postnatal subventricular layers is addressed more fully in the Discussion.

\section{MAP2 versus T'uJI immunolabeling in the proliferative zones of the developing telencephalon}

To further characterize and determine the other indices of neuronal differentiation exhibited by the TuJ1-positive cells of the proliferative zones, we stained the cmbryonic tclencephalon for another known neuron-specific marker, the microtubule-associated protein 2 (MAP2; Johnson and Jope, 1992). This molecule has been shown to be present in postmigratory, differentiating neurons, and first appears in cells of the subplate and marginal zones before being detected in the later generated cortical plate (Crandall et al., 1986; Chun and Shatz, 1989). As MAP2 belongs to a family of developmentally regulated isoforms (Johnson and Jope, 1992), we have used two antibodies that are known to recognize all isoforms of this molecule (MAP23, Chun and Shatz, 1989; HM2, Tucker et al., 1988), and in particular the embryonic low-molecular-weight form, MAP2c, which is expressed earlier than other forms (Riederer and Matus, 1985).

MAP2 staining of the developing telencephalon followed the TuJ1 labeling with a $1 \mathrm{~d}$ lag. MAP2 immunoreactivity was detected only in the layers which are known to contain postmitotic neuronal cell bodies and/or dendrites: the preplate, marginal zone, cortical plate, and subplate. However, the ventricular and subventricular zones were never labeled above background, even along their interface where there are numerous TuJ1-positive cells (Fig. 6). Even at postnatal ages P0 and P5, when the subventricular zone was crowded by $\mathrm{TuJ} 1$-positive cells and processes, no MAP2-specific expression was seen in these layers (Fig. 5d,e).

\section{TuJ1 immunoreactivity in the ventricular and subventricular zones of the developing striatum}

The labeling of the cortical proliferative zones was comparcd to that of the striatum because of their proximity and similar embryonic origin. Until E14, most of the proliferative layers of the striatum, collectively referred to as the ganglionic eminence (GE), remained devoid of $\mathrm{TuJ} 1$ labeling. Labeling was restricted to the striatal primordium where most of the early postmitotic neurons of the striatum are localized (Fig. 1).

TuJ 1 labeling of the striatal proliferative zones becomes apparent between E14 and E15 (Fig. 1). The striatal germinal zone exhibited two different staining patterns that corresponded closely, but not strictly, to the ventricular and subventricular zones of this area. In the outer part of the ganglionic eminence, within the striatal subventricular zone, staining was uniform and dense without the presence of the band-like pattern of expression characteristic of the cortical subventricular zone. Along the ventricular surface, the staining developed following a dorsoventral gradient (compare with Fig. 7). Initially $\mathrm{TuJ} 1$-positive cells were restricted to a dense aggregation ventral-medial to the caudatopallial angle, which clearly demarcated the border between the cortical and striatal ventricular zones (Fig. 4). This aggregation is present as early as E14 and persists until E17, when it is masked by the increasing numbers of TuJ1-positive cells in ventricular zones of both structures. TuJ 1 -positive cells of the striatal ventricular zone, as in its cortical counterpart, were labeled very strongly, with many radially and tangentially oriented TuJ1-positive cells. Comparable to the cortical ventricular and subventricular zones, the TuJ1-positive cells of the ganglionic eminence did not express detectable MAP2 immunoreactivity (Fig. 7).

Similar to the cerebral cortex, as neuronal proliferation ceases, the labeling in the striatal ventricular zone subsides, but remains high in the subventricular zone (Fig. 5). Interestingly, the labeling density of the subventricular zone of the striatum is much denser than the labeling of its cortical counterpart. This becomes apparent at E19 and persists until the last age examined, P5 (Fig. 5d,e).

\section{BrdU labeling of TuJ1-positive cells in the ventricular and subventricular zones of the developing cerebral cortex}

To determine the birthdates and the proliferative activity of the $\mathrm{TuJ} 1$-positive cells within the ventricular and subventricular zones, bromodeoxyuridine (BrdU) was injected intraperitoneally into pregnant dams according to three different pulsechase schedules (Table 2), with three different objectives in mind: a $1 \mathrm{hr}$ survival after injections at E14-E17, to identify proliferating cells in S-phase; injections at E11 and E12, followed by

majority of the cells within this band are horizontally oriented bipolar cells (arrows) with their leading (longer) process pointed medially (to the right). Fewer in numbers, radially (small arrowhead) and obliquely (large arrowhead) oriented cells can also be found. $d$, Examples of radially oriented TuJ1-positive cells (arrowheads) in the ventricular zone of the E16 cerebral wall. The radially elongated bipolar cell to the left is a very rare finding. The more common radially oriented cell present in the ventricular zone is shown to the right, with none of its process touching the ventricular surface. $e$ and $f$, High-magnification photomicrograph of the TuJ1-stained proliferative zones from the E17 scction shown in Figure $2 e$, and adjacent section stained with hematoxylin-eosin. Note that TuJ1-positive cells are concentrated in the lower half of the subventricular zone, where many horizontally oriented cells can be seen (arrows). The ventricular zone, now reduced to half of its maximum size, also contains many TuJ1-positive cells. Arrowheads point to the trajectory of a long and crooked process of a horizontally oriented cell in the ventricular zone (long arrow). $V$, lateral ventricle. Scale bars, $50 \mu \mathrm{m}$. 

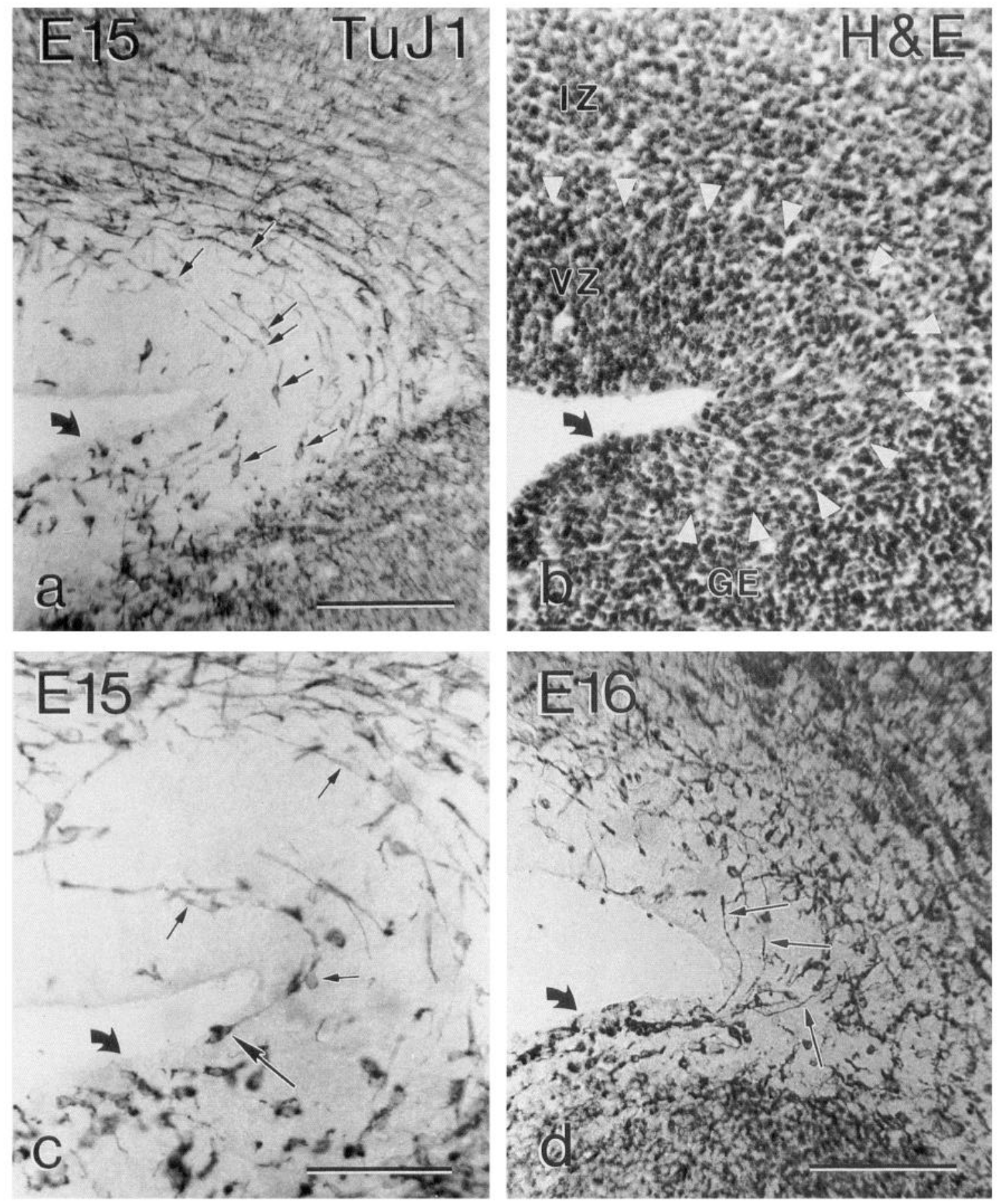

Figure 4. TuJ1 immunoreactivity in the proliferative zones forming the caudatopallial angle at E15 and E16. a, High-magnification photomicrograph of the area designated by brackets in Figure 1. Many TuJ1-positive cells (arrows in the ventricular zone) seem to follow a curved trajectory circling the caudatopallial angle. The presence of a leading (longer) process in most of these cells suggests ongoing migration toward the dorsomedial part of the cerebral wall. $b$, Section adjacent to $a$ stained for hematoxylin-eosin to show the borders of the cortical ventricular zone (arrowheads) and the transition between the cortical and striatal ventricular zones (curved arrow). Note that the cortical ventricular zone seems to encircle the caudatopallial angle. It is also of interest that the aggregation of TuJ1-positive cells on the ventral side of the caudatopallial angle in $a$ coincides with the border between the cortical and striatal ventricular zones. c, A TuJ1-positive cell body (long arrow) within the ventral side of the caudatopallial angle extends a long process that curves around the angle. Arrows point to other horizontally oriented cells circling this region. $d$, Representative example of the caudatopallial angle at E16, showing a clear invasion of the dorsal side by long processes (arrows) of cells with their soma's in the ventral side. Curved arrows in $c$ and $d$ point toward the presumed border between the cortical and striatal ventricular zones. Scale bars: $a, c$, and $d, 100 \mu \mathrm{m}$; for $b, 50 \mu \mathrm{m}$.

a $4 \mathrm{~d}$ survival period to label the subplate population (Wood et al., 1992); and finally, a $24 \mathrm{hr}$ survival period after injections at E14-E16, to label young postmitotic cells generated during the peak of neurogenesis.
BrdU is incorporated by all cells in S-phase of the cell cycle at the time of the injection. The cells that incorporate the BrdU may continue to divide again, thereby diluting their BrdU content, or become postmitotic and retain all of the BrdU incor- 

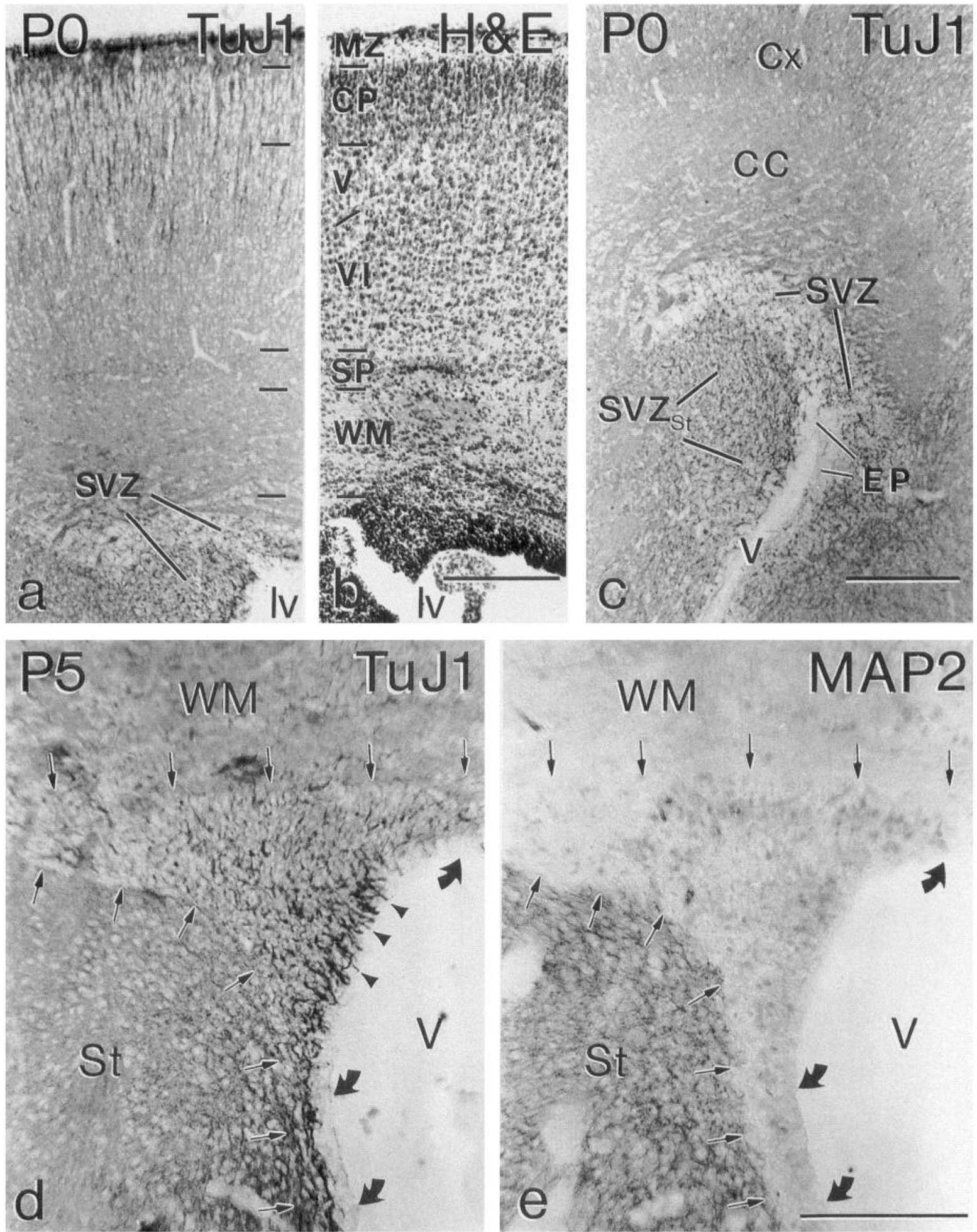

Figure 5. Pattern of class III $\beta$-tubulin expression in the cerebral wall and proliferative zones, at P0 and P5. $a$ and $b$, Two adjacent coronal sections of the cerebral wall at P0 stained for TuJ1 $(a)$ and hematoxylin-eosin $(b)$. In the subventricular zone, surrounding the ependymal lining, intensely stained cells and processes stand out against a pale unlabeled background. This is in contrast to the almost uniform TuJ1 staining of the remaining cerebral wall. $c$, A more anterior section at the level of the genu of the corpus callosum $(C C)$, showing in detail the ependyma $(E P)$ and subventricular zones of the cerebral cortex $(S V Z)$ and striatum $\left(S V Z_{S t}\right)$. The ependyma is practically devoid of TuJ1-positize cells, although the subventricular zones show a very dense population of labeled cells. Notice the particularly high density of labeling in the striatal subventricular zone. $d$ and $e$, A high-magnification photomicrograph of the ependyma and subventricular zone at P5 from adjacent coronal sections stained for TuJ1 $(d)$ and MAP2 $(e)$ TuJ1 immunoreactivity remains high in the subventricular zone (demarcated by arrows). The curved arrows point to the ependymal lining, where TuJ1 immunoreactivity is absent, except at the dorsolateral angle of the ventricular wall (arrowheads). There some TuJ1-positive processes originating from within the subventricular zone reach the ventricular surface. In contrast to the TuJ1 staining, MAP2 (e) does not label the ependyma or subventricular zone. $V$, ventricle. Scale bars: $a-c, 100 \mu \mathrm{m} ; d$ and $e, 50 \mu \mathrm{m}$. 

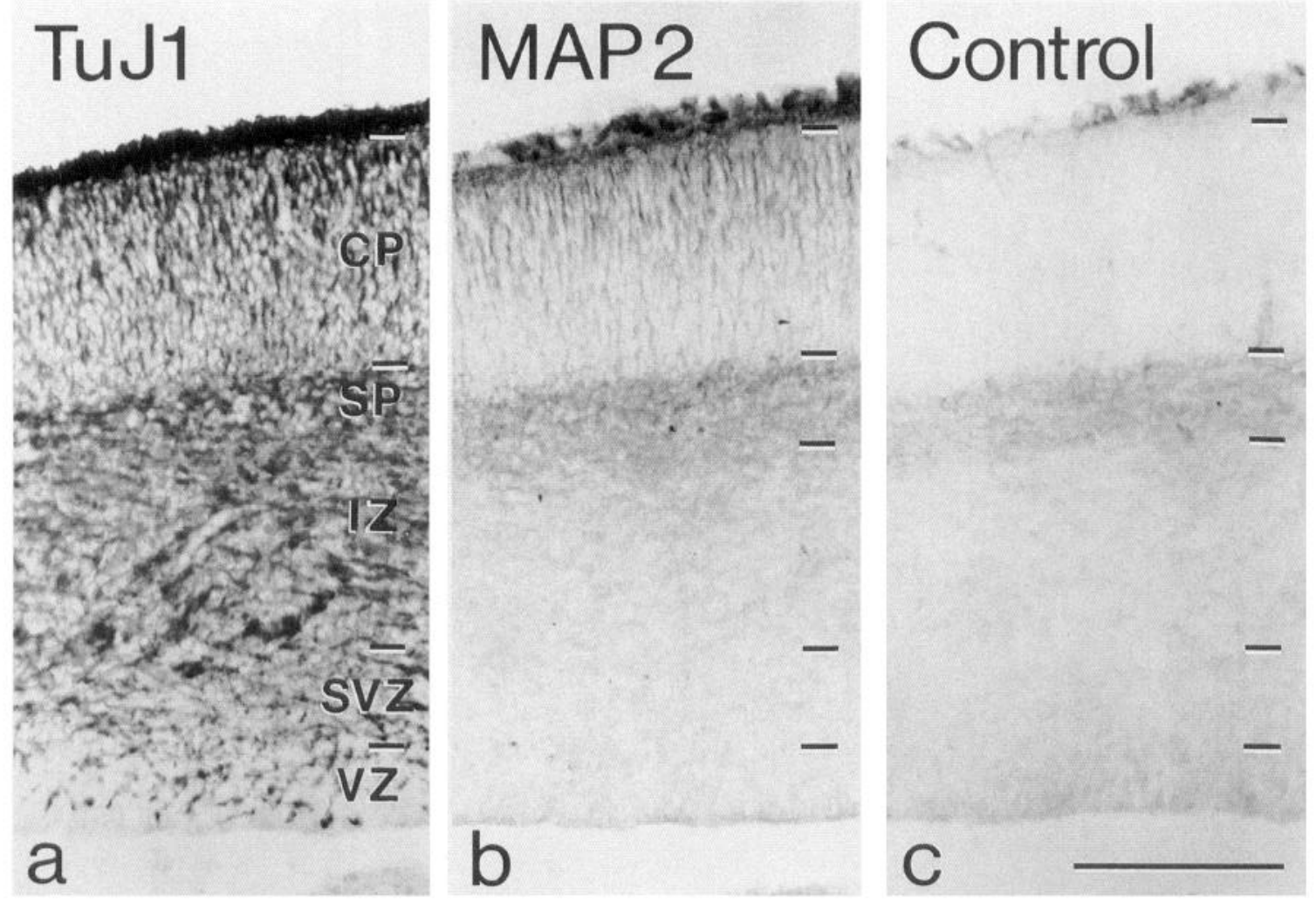

Figure 6. Comparison of TuJ1 and MAP2 labeling in the dorsolateral cerebral wall at E16: three adjacent coronal sections stained for TuJ1 (a), MAP2 $(b)$, and control $(c) . a$, TuJ1 staining is prominent in all layers of the cerebral wall. $b$, In contrast to the TuJ1 staining, MAP2 is not expressed in the ventricular zone $(V Z)$, subventricular zone $(S V Z)$, or the intermediate zone $(I Z)$. MAP2 staining is restricted to the upper layers, subplate $(S P)$, cortical plate $(C P)$, and marginal zone $(M Z)$, where the cell bodies of more mature neurons are found. $c$, Due to nonspecific avidin binding the control section shows high background staining in spatial register with the subplate. This nonspecific binding is easily distinguishable from the specific antibody binding by color and intensity. Scale bar, $150 \mu \mathrm{m}$.

porated. The nuclei of the BrdU-containing cells were labeled as described previously (Takahashi et al., 1992, 1993). Heavily labeled cells were identified by the complete or almost complete staining of their nucleus, whereas weakly labeled cells had only speckles of fluorescence inside the nucleus; a full range of intermediate patterns was observed. In all cases examined, background was virtually nonexistent. After long postinjection survival periods ( $>1$ d) a large number of cells had some BrdU labeling inside their nuclei. This was most apparent when tissue was fixed with HistoChoice, indicating that HistoChoice is superior to paraformaldehyde for the detection of low numbers of BrdU molecules.

To determine if the TuJ1-positive cells of the ventricular and subventricular zones were capable of dividing, BrdU was given $1 \mathrm{hr}$ before death at E14, E15, E16, and E17. Except for a few BrdU-positive nuclei within the subventricular zone (Fig. 8, arrowhead), labeled cells were restricted to the upper third of the ventricular zone (Fig. 8), referred to as the synthetic zone (Takahashi et al., 1992, 1993). BrdU was not incorporated by TuJ1-positive cells after a $1 \mathrm{hr}$ survival at any embryonic day studied. This supports previous observations that class III $\beta$-tubulin expression begins after or during the last mitotic cycle (Lee et al., 1990a,b).

To investigate if some or all of the TuJ1-positive cells within the proliferative layers of the developing cerebral cortex were part of the subplate population, we have given BrdU injections to pregnant dams at the known birthdates of the subplate population in the mouse, E11 and E12 (Wood et al., 1992), and killed these animals $4 \mathrm{~d}$ later, when there is a prominent subplate. No cells within the proliferative zones were found to be double labeled (BrdU and TuJ1 positive) after an E11 injection of BrdU, although many cells were heavily labeled within the subplate and marginal zones. In contrast, after an E12 injection, heavily labeled BrdU-positive cells were present within the proliferative zones and some of these were found to be double labeled (Fig. 9a-d). This finding may simply reflect an outsidein gradient of neurogenesis of the marginal zone and subplate cells, as previously demonstrated (mouse, Wood et al., 1992; rat, Bayer and Altman, 1990; cat, Luskin and Shatz, 1985). If so, then this would argue that some TuJ1-positive cells within the proliferative zones may be a subpopulation of subplate cells. However, E12 injections have also labeled cells within the cortical plate (Fig. 9a), indicating that there is some degree of overlap of cell types being generated on any one day. Furthermore, only a small fraction of TuJ1-positive cells in the ventricular and subventricular zones were in fact double labeled after an E12 injection. Many TuJ1-positive cells within the proliferative zones were weakly BrdU positive or not at all, indicating that some, if not the majority, of these cells and their precursors have undergone more than one round of proliferation after the BrdU injections. This observation argues that the TuJ1positive cells of the proliferative zones are a separate population from the subplate cell population.

The increasing number of TuJ 1-positive cells within the proliferative zones during the period of cortical neurogenesis suggests the continued generation of these cells. To investigate this 

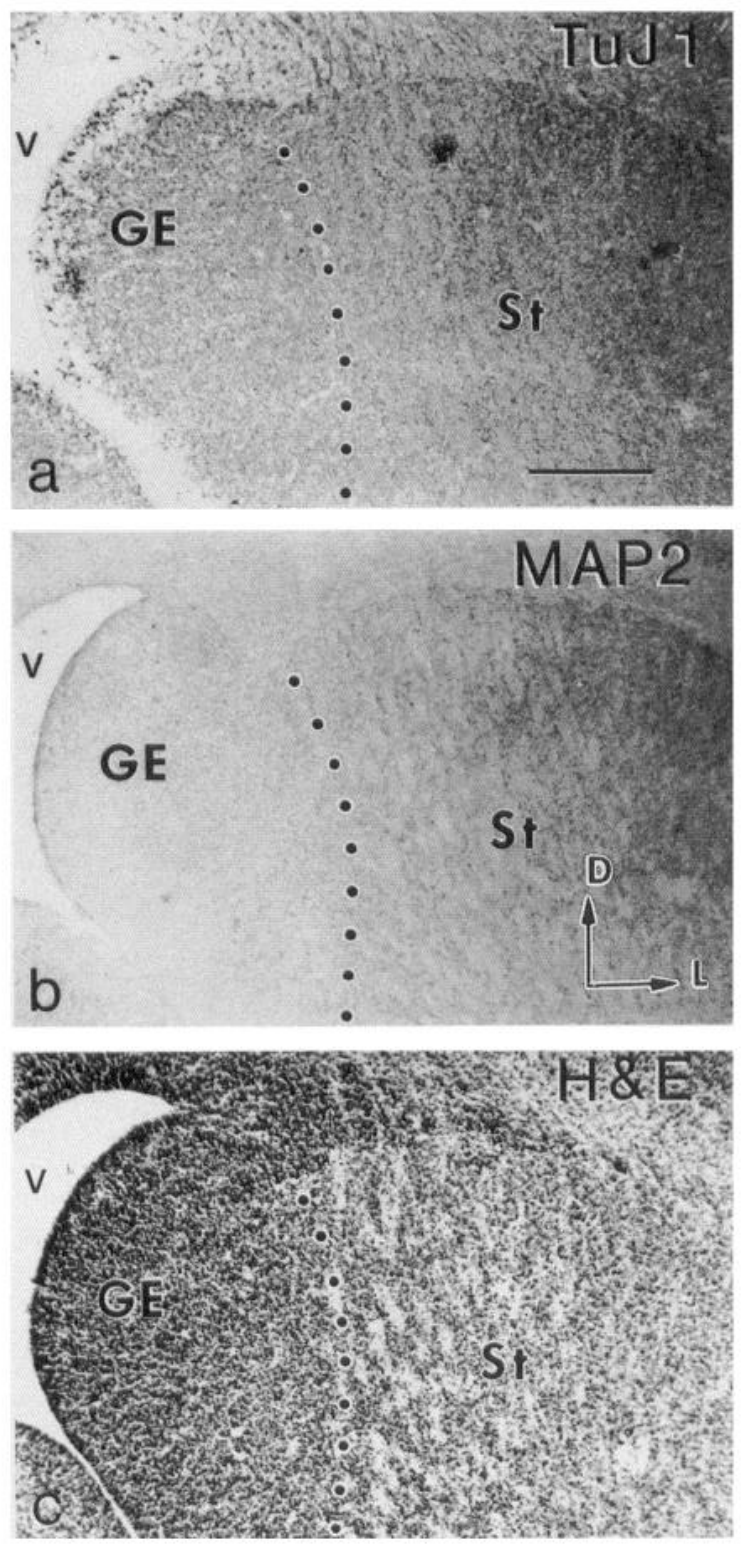

Figure 7. Comparison of $\mathrm{TuJ} 1$ and MAP2 labeling in the ganglionic eminence at E16. Shown are three adjacent coronal sections stained for $\mathrm{TuJ} 1(a)$, MAP2 (b), and hematoxylin-eosin (c). The dotted line separates the striatal primordium $(S t)$ from the proliferative zones (ventricular and subventricular zones), collectively called the ganglionic eminence $(G E)$. a, TuJ1 immunoreactivity is evenly distributed over the outer portion of the ganglionic eminence (which corresponds to the striatal subventricular zone). Within the ventricular zone, close to the lumen $(V)$, only a fraction of the cells are labeled. Note the dorsal-to-ventral gradient of the TuJ1 labeling along the ventricular surface of the ganglionic eminence (compare to the E15 ganglionic eminence shown in Fig. 1). $b$, In contrast to the TuJ1 staining, MAP2 is absent from the ganglionic eminence and restricted to the striatal primordium composed of more mature postmitotic neurons. $c$, The striatal primordium is defined by the less compact cell packing density as compared to the ganglionic eminence, and by the presence of pale striated patches, which represent fiber bundles of the internal capsule, that traverse it. $D$, dorsal; $L$, lateral. Scale bar, $100 \mu \mathrm{m}$.

possibility directly, pregnant dams were injected with BrdU at E13, E14, or E15 and killed 1 d later. After a 24 hr postinjection survival, alternating horizontal bands of heavy and lightly labeled nuclei were found in the cerebral wall (Fig. $9 e$ ). Few cells had yet reached the cortical plate during this period at any age

\begin{tabular}{|c|c|c|c|c|c|c|}
\hline \multirow{3}{*}{$\begin{array}{l}\text { Age of } \\
\text { animal } \\
\text { at fix- } \\
\text { ation }\end{array}$} & \multirow{3}{*}{$\begin{array}{l}\text { Number } \\
\text { of } \\
\text { brains }\end{array}$} & \multirow{2}{*}{\multicolumn{2}{|c|}{ Fixative $^{a}$}} & \multicolumn{3}{|c|}{ Survival } \\
\hline & & & & \multirow[b]{2}{*}{$1 \mathrm{hr}$} & \multirow[b]{2}{*}{$24 \mathrm{hr}$} & \multirow{2}{*}{$\begin{array}{l}4 \\
\text { days }\end{array}$} \\
\hline & & Para & Histo & & & \\
\hline E14 & 4 & 2 & 2 & 2 & 2 & - \\
\hline E15 & 7 & 3 & 4 & 3 & 2 & 2 \\
\hline E16 & 6 & 3 & 3 & 2 & 2 & 2 \\
\hline E17 & 1 & - & 1 & 1 & - & - \\
\hline
\end{tabular}

BrdU was given intraperitoneally to pregnant dam.

${ }^{a}$ Para, $4 \%$ paraformaldehyde; Histo, HistoChoice.

studied (Fig. 9e). The presence of two heavily labeled bands suggests two different sets of recently postmitotic cells. The upper band, high in the intermediate zone, is believed to be made of postmitotic neurons destined for the cortical layers (Altman and Bayer, 1990); most, if not all, of these cells were TuJ1 positive (not shown). The second band of heavily labeled nuclei was found to coincide with the lower border of the subventricular zone. This second band of cells was previously considered to consist of slower migrating neurons that eventually would resume migration, and advance toward the cortical plate (Altman and Bayer, 1990). If this hypothesis is true, many of the cells of the lower BrdU band should be double labeled with $\mathrm{TuJ}$ 1, similar to the cells of the upper BrdU band. Surprisingly, not many cells within this second, lower band were found to be double labeled. Indeed, this band seemed to be surrounded by TuJ1-positive cells (Fig. 9c). Although fewer than expected, some $\mathrm{TuJ} 1$-positive cells within the proliferative zones could be found to be double labeled after a $24 \mathrm{hr}$ postinjection survival at all of the days studied: E13-E14, E14-E15, and E15-E16. This suggests that the TuJ1-positive cells found in the proliferative zones are generated over an extended period of time. However, it is still not possible to differentiate which of these TuJ1-positive/BrdU-positive cells will remain in the proliferative zones and which will leave the proliferative zones en route to the cortical plate.

\section{Discussion}

With the use of a monospecific antibody $(\mathrm{TuJ} 1)$ against the class III neuron-specific isotype of $\beta$-tubulin (Lee et al., 1991a,b), we have described the presence of a population of cells, presumably neurons, residing in the proliferative zones of the developing cerebral cortex and striatum. The cells, characterized by intense TuJ1 immunoreactivity, appeared shortly after the onset of cortical and striatal neurogenesis and increased in number as neurogenesis proceeded. Although the TuJ1-positive cells were present throughout the ventricular and subventricular zones and exhibited a variety of morphological configurations, the majority were situated at the interface of the ventricular and subventricular zones and were oriented in the tangential plane, suggesting that they were engaged in nonradial migration. Furthermore, TuJ1 immunoreactivity remained high in the postnatal subventricular zone even after the ventricular zone had regressed. We were able to further distinguish the TuJ1positive cells of the proliferative zones as a unique population of postmitotic neurons by their extended period of neurogenesis and because they did not express another neuron-specific molecule, MAP2 (Fig. 10). 

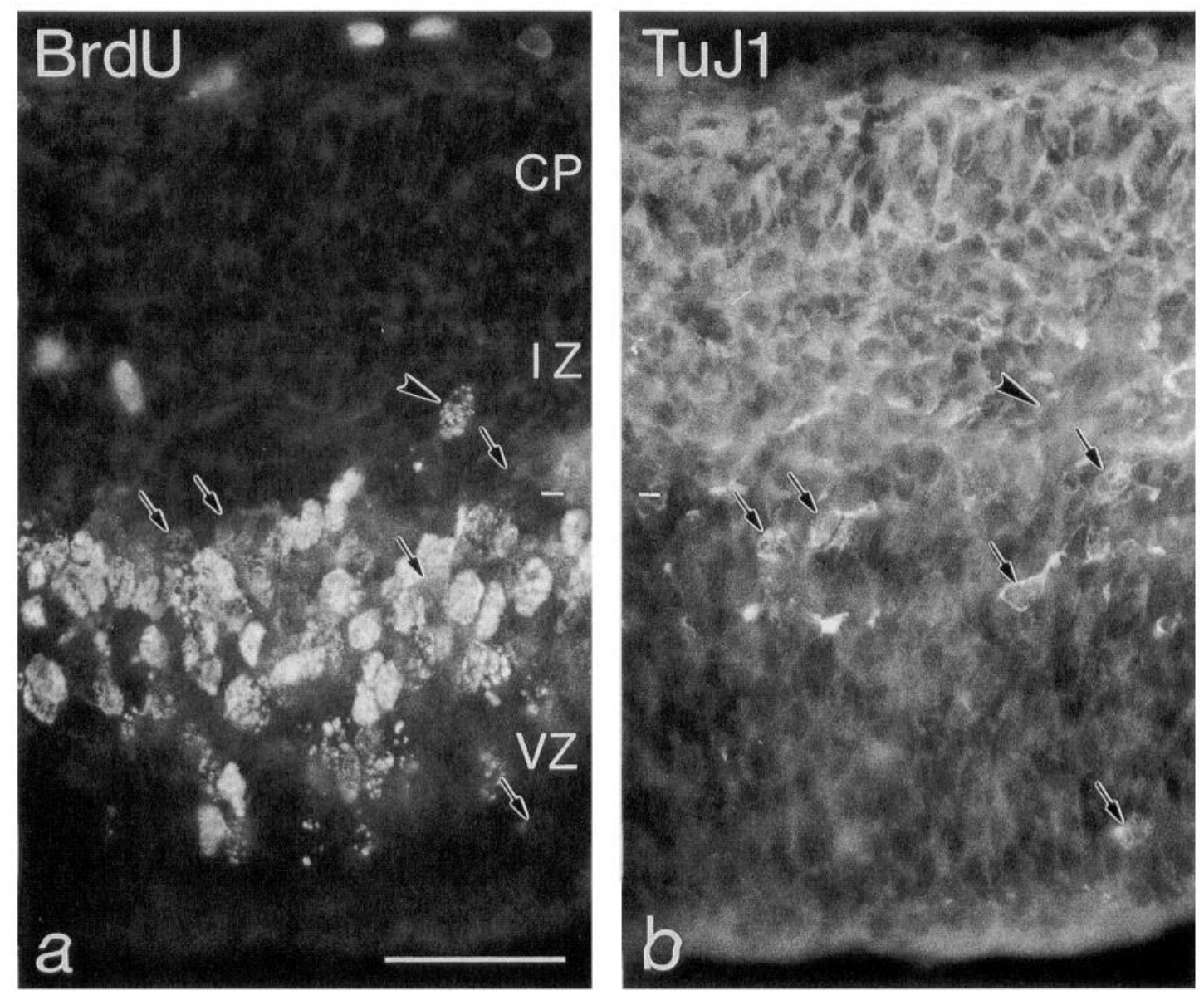

Figure 8. S-phase cells in the ventricular and subventricular zones do not express class III $\beta$-tubulin immunoreactivity. Photomicrographs of the same coronal section of the E15 medial cortical wall stained for BrdU $(a)$ and TuJ1 immunoreactivity $(b)$. BrdU was injected in a pregnant dam an hour prior to death. $a$, BrdU immunoreactivity was revealed by a rhodamine-conjugated secondary antibody. The labeled cells have varying degrees of nuclear labeling, reflecting different BrdU uptake due to the asynchronous mitotic behavior of this population. The BrdU-positive cells are located in the upper half of the ventricular zone, although a few may appear in the subventricular zone (arrowhead). $b$, TuJ1 immunoreactivity was revealed by an FITC-labeled secondary antibody. The bulk of the TuJ1 labeling is above the ventricular zone $(V Z)$ with a few TuJ1-positive cells within it (arrows). As in all other areas analyzed, no TuJ1-positive cell was found to be double labeled $1 \mathrm{hr}$ after a BrdU injection. Scale bar, $50 \mu \mathrm{m}$.

\section{Technical considerations}

Several aspects of the staining further confirm that only neurons are labeled by TuJl. First, the cells of non-neuronal structures, such as the ependyma, choroid plexus, blood vessels, and pial membranes, were not stained with TuJ1. Second, except for the proliferative zones, the intensity of labeling associated with any given layer of the developing cerebral cortex and striatum correlated well with the degree of maturation of the neurons known to occupy the layer. For example, at E14, the oldest neurons of the developing cerebral cortex, those of the marginal zone and subplate, displayed more intense labeling than those of the interposed cortical plate, composed of younger, not fully developed, recently postmigratory neurons (Figs. $1,2 b, 3 a$ ). Third, the adult brain was uniformly stained, indicating that the antibody labels all neurons with a similar intensity (not shown). Furthermore, we have found that in hippocampal mixed neuronal-glial cell cultures fixed either with HistoChoice or paraformaldehyde, only neurons-GFAP-negative cells-were labeled with TuJ1 (Menezes and Luskin, unpublished observations). In conclusion, these results, together with the known antibody specificity (Lee et al., 1991a,b) and the neuron- specific distribution of the class III $\beta$-tubulin isotype (Sullivan, 1988; Lee et al., 1991a,b), firmly demonstrated that the cells tagged with the TuJ1 antibody are neurons or belong to a neuronal lineage.

\section{TuJ1-positive cells of the proliferative zones are a distinct population}

Given that the acquisition of neuronal characteristics is principally a postmigratory phenomenon (Miller, 1988; Tohyama et al., 1991), the presence of heavily labeled TuJ1-positive cells in the ventricular and subventricular zones was initially an unexpected finding. Previous studies had indicated that newly generated neurons exit the ventricular zone upon becoming postmitotic, so even more surprising was the persistent presence of postmitotic cells within the ventricular zone a number of days after they had been generated. This was directly demonstrated by the presence of BrdU immunoreactivity in TuJ1-positive cells of the proliferative zones several days after the administration of BrdU (Fig. 9c,d). Although it is now well established that the ventricular zone has a heterogeneous cellular composition (McConnell, 1991; Luskin, 1993), cumulative labeling 
with BrdU, at E14, has indicated that virtually all of the cells present in this layer contribute to the proliferative pool (Takahashi et al., 1993). Therefore, the stable nonmitotic component represented by the $\mathrm{TuJ} 1$-positive cells may have been underestimated because of the very low density of these cells within the proliferative zones at E14. It is possible that the proportion of proliferating cells of the ventricular zone may decrease at older embryonic ages as the proportion of $\mathrm{TuJ} 1$-positive cells within the ventricular zone increases.

The TuJ 1-positive cells of the proliferative zones share several features that justify categorizing them as a distinct population. Most significantly, they all exhibit a high intensity of staining by the TuJ1 antibody (Figs. 1, 2, 3a) when compared to other postmitotic neurons within the intermediate zone, subplate, and cortical plate. This suggests that the TuJ1-positive cells of the proliferative zones are a separate population from the neurons destined for the cortical plate, unless postmitotic neurons bound to the cortical plate downregulate their expression of $\mathrm{TuJ} 1$ as they exit the proliferative zones. The latter seems unlikely because of the gradual increase in the level of TuJ 1 expression by cortical neurons as they mature. In addition, the number of TuJ1-positive cells found within the proliferative zones during the period of neurogenesis is not sufficient to account for the full complement of postmitotic neurons being generated at any one time. We know this by comparing the number of TuJ1positive cells in the proliferative zones to the number of cells that become postmitotic on any given day as revealed by the incorporation of BrdU (see Results). These results suggest that the TuJ 1-positive cells of the ventricular zone represent a subset of the neuronal population being generated in the ventricular and subventricular zones. Finally, the birthdates of the TuJ1positive cells in the proliferative zones combined with their lack of MAP2 expression, a marker of postmigratory neurons (Crandall et al., 1988; Tucker et al., 1988; Tohyama et al., 1992; Johnson and Jope, 1993), set them apart from the transient subplate cell population underlying the cortical plate (Luskin and Shatz, 1985; Shatz et al., 1988; Chun and Shatz, 1989). The cells of the subplate, which are born before the cells of the cortical plate, express both TuJ1 and MAP2 (Figs. 5, 6). Therefore, if the TuJ1-positive cells of the proliferative zones were simply a deep extension of the subplate, then they should also express MAP2 with similar intensity. Thus, the differences in the birthdates between subplate cells and the $\mathrm{TuJ} 1$-positive cells of the proliferative zones combined with their differences in staining argue that they are distinct populations. Nonetheless, it is possible that like the subplate cells, the $\mathrm{TuJ} 1$-positive cells of the proliferative zones are transitory (Luskin and Shatz, 1985; Shatz et al., 1988).

\section{The TuJ1-positive cells of the proliferative zones are possibly migratory}

Some properties of the incorporation of class III $\beta$-tubulin isotype by microtubules are consistent with a view that the TuJ1positive cells of the proliferative zones are highly dynamic and possibly migratory. Microtubules are in a state of "dynamic instability"; that is, microtubule polymers are in a process of constant growth and shrinkage (Mitchison and Kirschner, 1988). For simplicity's sake, it could be said that the rate of polymerization versus depolymerization dictates the stability of the microtubule polymer and consequently the ability of cells to change their conformation. Because of the inherent instability of the microtubule polymer, a decrease in rate of polymerization is presumed to increase the plasticity of microtubule assembly. In this regard, the class III $\beta$-tubulin isotype may not favor microtubule polymerization since it is not readily incorporated into neuronal microtubules compared to other $\beta$-tubulin isotypes (Joshi and Cleveland, 1989). In fact, a high concentration of the class III isotype may even inhibit microtubule polymerization since it was demonstrated that the absence of class III $\beta$-tubulin increased microtubule assembly in in vitro microtubule reconstitution experiments (Banerjee et al., 1990). Furthermore, Ferreira and Carceres (1992) have recently demonstrated, using ccrcbcllar cell cultures, that the neuron-specific $\beta$-tubulin isotype does not participate in the early steps of neuronal maturation, such as dendritic elongation and axonal extension, in accordance with the view that the class III $\beta$-tubulin is not involved in microtubule stabilization. Taken together, these results suggest that the presence of the class III $\beta$-tubulin isotype facilitates structural rearrangements of the cytoskeleton by increasing the dynamics of the microtubule assembly. Thus, the elevated presence of this isotype may engender cells with the capacity to rapidly change their conformation.

The bipolar morphology of many of the TuJ1-positive cells in the proliferative zones, particularly at the border between the ventricular and subventricular zones (Figs. $3 a-c$, 4), is similar to that exhibited by migrating cells (Rakic, 1972; O'Rourke et al., 1993). In addition, the tangential orientation of a large proportion of the TuJ l-positive cells indicates the probable direction of migration of this population. A tangential migration differs from the radial direction of migration believed to be the predominant mode of migration of neurons destined for the cerebral cortex (Rakic, 1972; Luskin et al., 1988; Misson et al., 1991b). However, O'Rourke et al. (1992) have directly demonstrated, in cultured slices of the developing cerebral cortex, cells that migrate perpendicular to radial glial processes in the intermediate zone, with morphologies matching that of the TuJ1positive cells of the proliferative zones. They surmised that the tangentially migrating cells are responsible for the lateral dispersion of clonally related cells in the developing cerebral cortex, reported by Walsh and Cepko $(1992,1993)$. However, it is conceivable that some of the cells tracked by O'Rourke et al. (1992) are part of the tangentially oriented population of $\mathrm{TuJ} 1$ positive cells described here, which may never reach the cortical plate.

The tangential orientation of a substantial fraction of the TuJ1positive cells of the proliferative zones is a strong indication that they do not advance along radial glial fibers. An alternative guidance mechanism that has been proposed is based on neuronto-neuron interactions (Rakic, 1972), such that cells would be directed to migrate along axonal processes. However, this mode of migration for the $\mathrm{TuJ} 1$-positive cells of the proliferative zones can also be ruled out, based on the TuJ1 staining pattern of neuronal processes in the developing telencephalon. It is evident that there are no axonal processes at the ventricular-subventricular border where these cells are located (Figs. 3, 4). Therefore, it is likely that the $\mathrm{TuJ} \mathbf{1}$-positive cells are following other cues, still to be determined. Interestingly, the border between the ventricular and subventricular zones, where most of the tangentially oriented cells reside, overlaps with the area where the fascicles of radial glial fibers of the developing cerebral cortex defasciculate (Misson et al., 1991a,b). This area of defascicu- 

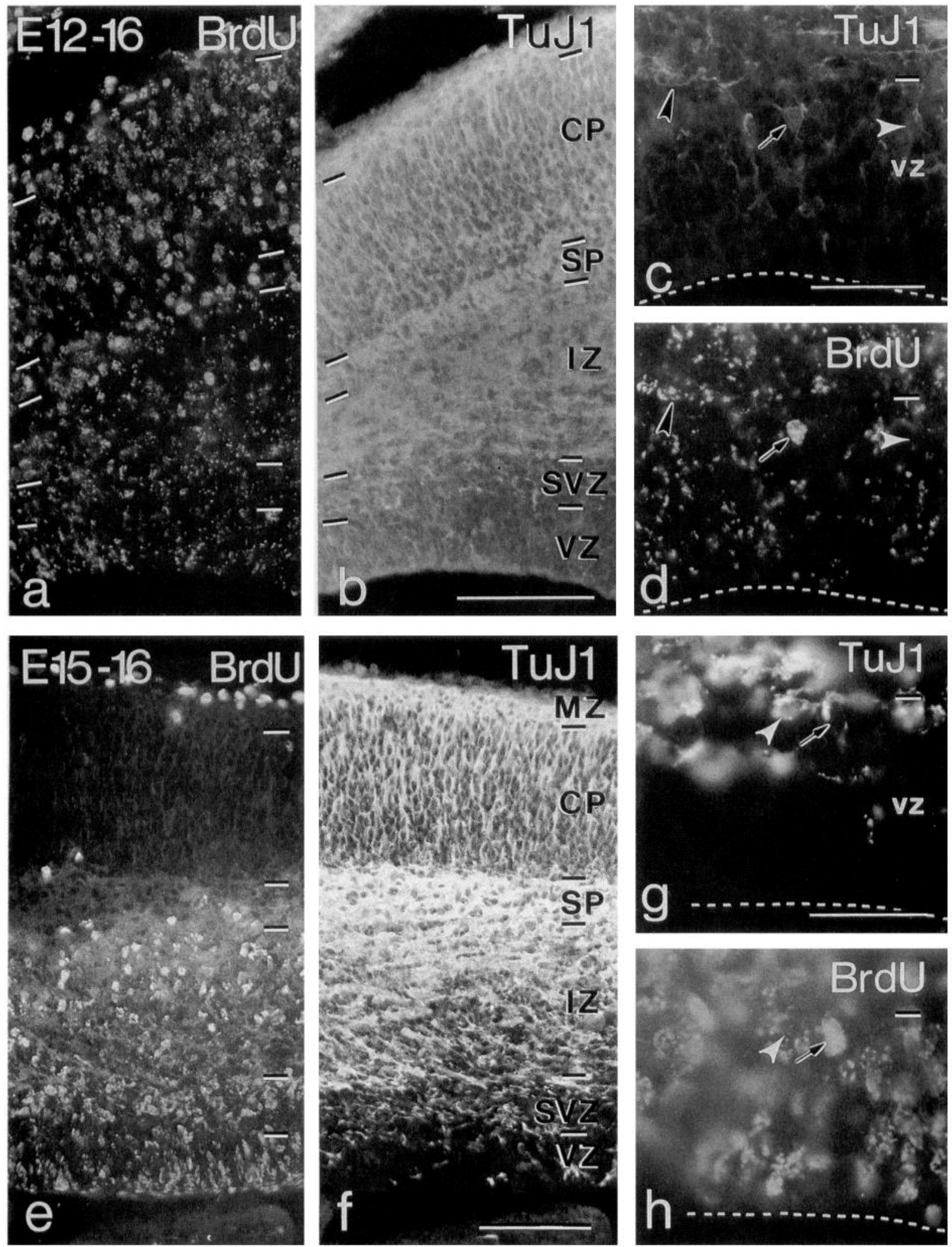

Figure 9. Photomicrographs of the E16 cerebral wall showing that TuJ1-positive cells are generated throughout the period of cortical neurogenesis. Coronal sections of E16 brains of animals that have received a BrdU injection at E12 $(a-d)$ or E15 $(e-h)$. $a$, Heavily labeled cells in the developing cerebral cortex $4 \mathrm{~d}$ after an E12 BrdU injection were predominantly found in the in subplate (SP), and a lower number occurred in the marginal zone $(M Z)$ and cortical plate $(C P)$. A few heavily labeled cells could be found in the intermediate zone (IZ), subventricular zone (SVZ), or ventricular zone $(V Z) . c$ and $d$, Examples of double-labeled, TuJ1-positive/BrdU-positive cells along the border between the ventricular zone and subventricular zone that were heavily labeled (arrow) and lightly labeled (arrowhead) with BrdU, as well as a TuJ1-positive/BrdU-negative cell (white arrowhead). $e$ and $f$, One day after an E15 BrdU injection, heavily labeled cells were distributed in two distinct bands, one at the upper half of the intermediate zone and the other within the subventricular zone. Compare the location of the lower band of heavily labeled BrdU nuclei $(e)$ with the TuJ1 labeling 
lation may provide a channel through which $\mathrm{TuJ} 1$-positive cells migrate tangentially.

\section{Additional neuronal features of the TuJ1-positive cells of the proliferative zones}

If the TuJ1-positive cells of the proliferative layers are indeed neurons, then it is reasonable to expect that they express other neuron-specific molecules. However, no other neuron-specific marker tested, including antibodies to neurofilaments, has been localized to the cells of the cortical ventricular and subventricular zones (Schmechel and Marangos, 1983; Edwards et al., 1989; Kaplan et al., 1990). Nonetheless, an antibody against the highly polysialylated form of the neural cell adhesion molecule (NCAM-H), associated with migrating neurons, displayed a staining pattern in the rat embryonic cerebral cortex that partially matched the distribution of the TuJ1-positive cell population at the border between the ventricular and subventricular zones (Seki and Arai, 1991). However, the NCAM-H-positive cells cannot account for the full complement of $\mathrm{TuJ} 1$-positive cells described here; it is not yet clear if the NCAM-H-positive cclls rcpresent a subset of the TuJ1-positive cells in the proliferative zones. Another study (Cobas et al., 1991) described a band of cells stained with MAP2 at the border between the subventricular and intermediate zones, with very similar morphologies to the ventricular zone-subventricular zone TuJ1positive population. The discrepancy between the MAP2 pattern of staining obtained by Cobas et al. (1991) and ours, in which there was a lack of MAP2 staining in the proliferative zones, cannot be readily explained. Nevertheless, if TuJ1-positive cells in the proliferative zones do express MAP2 they do so at very low levels, different from other postmitotic neurons in the cortical plate and subplate, and undetected by our immunostaining assay (Figs. 5, 6).

Even though $\mathrm{TuJ}$ 1-positive cells of the proliferative zones do not appear to express any of the known neuron-specific markers tested, they may contain neurotransmitters. In several species some cells of the proliferative zones of the developing cerebral wall have been found to be GABA immunoreactive (human, Yan et al., 1992; monkey, Schwartz and Meinecke, 1992; rat, Van Eden et al., 1989; mouse, Cobas et al., 1991; Del Rio et al., 1992), Other neurotransmitters are also expressed by cells in the proliferative zones of the developing cerebral cortex, including VIP (Hajos et al., 1991), NPY (Chun and Shatz, 1989), and acetylcholine, revealed by choline acetyltransferase immunoreactivity (Parnavelas et al., 1988; Schambra et al., 1989). The GABA-immunoreactive cells were by far the ones that most closely resembled the $\mathrm{TuJ} 1$ population of the proliferative zones. We currently cannot rule out the possibility that all TuJ1-positive cells are GABAergic. However, given that other neurotransmitters are also found within the proliferative zones, the TuJ1-positive cells are probably diverse with respect to the neurotransmitter candidates they possess. Furthermore, our preliminary observations indicate that within the proliferative zones $\mathrm{TuJ} 1$-positive cells appear to be more numerous than GABA-immunoreactive cells. More importantly, our results argue against the previous notion which states that the neuro-

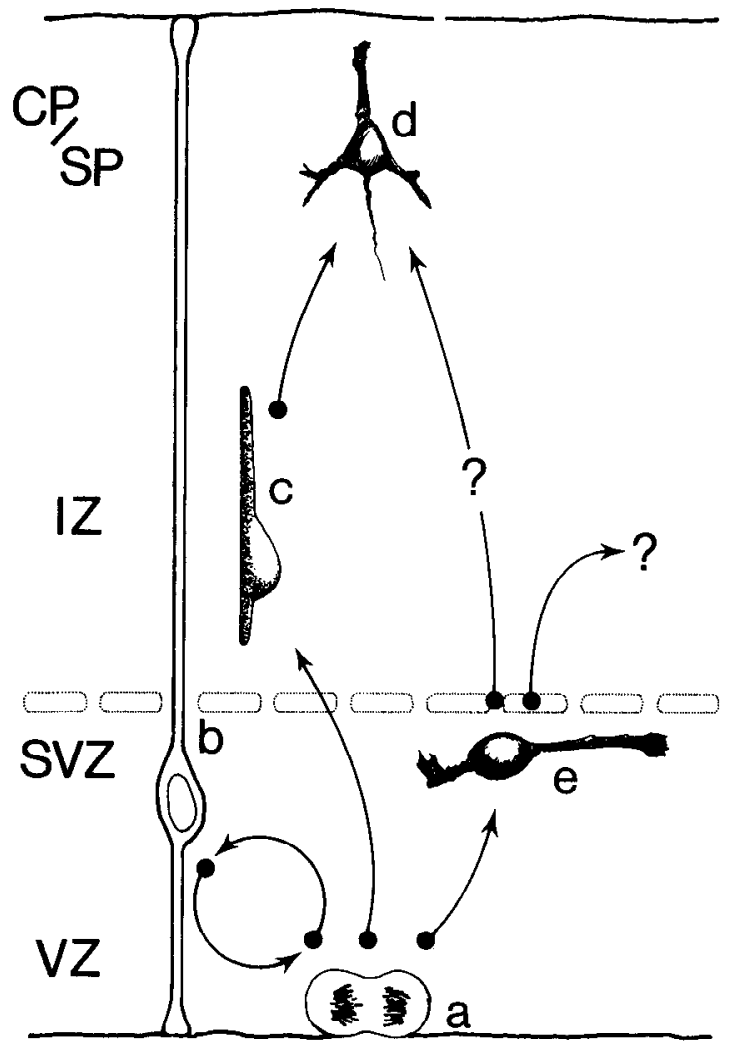

Figure 10. Summary of the expression pattern of class III $\beta$-tubulin in the developing cerebral cortex. Schematic representation of the cortical wall during neurogenesis. The cell types represented include progenitor cell undergoing cytokinesis $(a)$, radially oriented cell that retains proliferative potential, with processes extending the entire width of the cortical wall $(b)$, radially migrating postmitotic neuron $(c)$, subplate or cortical plate neuron undergoing differentiation $(d)$, and TuJ1-positive neuron within the proliferative layers $(e)$. Cells $e$ and $d$ express intense $\mathrm{TuJ} 1$ immunoreactivity, and cell $c$ may exhibit light staining, whereas cells $a$ and $b$ are never immunoreactive. Our results suggest threc different developmental alternatives for the progeny of a neuronal progenitor cell $(a)$. First, they may reenter the mitotic cycle and remain TuJ1 negative ( $a$ and $b$ ). Second, upon becoming postmitotic they may migrate $(c)$ immediately toward the cortical plate $(d)$ or, third, remain in the proliferative layers for an indeterminate period of time $(e)$. The final destination of the TuJ1-positive cells in the ventricular and subventricular zones $(V Z, S V Z)$ is unknown. They may migrate in a nonradial fashion and then invade the cortical plate (upper question mark), or remain in the proliferative zones where they may serve some temporary function and possibly be destined for programmed cell death (right question mark).

transmitter-containing cells of the proliferative zones either belong to the subplate cell population or are migrating cells destined for the cortical plate (Schambra et al. 1989; Van Eden et al., 1989; Cobas et al., 1991; Del Rio et al., 1992). Taken together, it is conceivable that a major subset of the neurotransmittercontaining cells are a distinct population of postmitotic neurons.

\section{The final destination of TuJ1-positive cells of the proliferative zones}

The final destination and ultimate fate of the $\mathrm{TuJ} 1$-positive cells found in the proliferative zones have not been determined. The

of the same section $(f)$. Note that this BrdU band does not have a corresponding TuJ1-positive band. $g$ and $h$, Although fewer in number than after an E12 injection, double-labeled cells within the proliferative zones could also be found in the E15-E16 BrdU experimental animals (arrow). TuJ1-positive cells that were either not labeled with BrdU (white arrowhead) or lightly labeled (not shown) were also present. Scale bars: $a, b$, $e$, and $f, 150 \mu \mathrm{m} ; c, d, g$, and $h, 50 \mu \mathrm{m}$. 
elevated expression of the class III $\beta$-tubulin isotype in these cells and their lasting presence within the proliferative zones allow them to be differentiated from the majority of neurons destined to populate the laminae of the cerebral cortex. However, because of the tangential morphology and possible migratory behavior of some of these TuJ1-positive cells, it could be conjectured that these cells are a part of the small contingent of neurons believed to migrate tangentially en route to the cortical plate (O'Rourke et al., 1992; Walsh and Cepko, 1992, 1993). Nevertheless, the presumed medial direction of migration of the TuJ 1-positive cells (Figs. 3, 4) is inconsistent with the predominantly lateral direction of dispersion predicted for the migrating cells destined for the cortical plate (Austin and Cepko, 1991; Misson et al., 1991a; Walsh and Cepko, 1992, 1993). Thus, the TuI1-positive cells of the proliferative zones identified in this study may constitute a separate population from the cells believed to undergo dispersion in the mediolateral plane studied by Walsh and Cepko $(1992,1993)$. Alternatively, the tangentially arrayed $\mathrm{TuJ} 1$-positive cells in the proliferative zones may never depart these layers, and like the subplate population may be eliminated by cell death (Luskin and Shatz, 1985; Shatz et al., 1988).

The increase in the number of $\mathrm{TuJ} 1$-positive cells during and after the period of cortical neurogenesis as well as their persistence in the highly proliferative postnatal subventricular zone is a puzzling finding (Fig. 7). In addition, the presence of a neuronal marker within the cells of the subventricular zone is seemingly inconsistent with the belief that this zone is mainly devoted to the production of glia (Privat, 1975; Mares and Bruckner, 1978). Two hypotheses can be put forward to reconcile the apparent incongruities. First, the TuJ1 immunoreactivity present in the postnatal subventricular zone may be recognizing another molecule closely related to the class III $\beta$-tubulin. This would imply that the TuJ1-positive cells of the postnatal subventricular zone were of a non-neuronal nature. On the other hand, the postnatal subventricular zone may contain a special population of proliferating cells that expresses the class III $\beta$-tubulin. Both hypotheses need further investigation, although we favor the second possibility in light of recent findings related to the composition of the postnatal subventricular zone. It has been shown that a discrete part of the subventricular zone is a prolific source of neurons destined for the olfactory bulb (Luskin, 1993). Furthermore, these cells may be similar to the bipotential progenitor cells of the adult striatum that are capable of generating both neurons and glia (Reynolds and Weiss, 1992). Thus, the postnatal subventricular zone may contain two populations of cells, one dedicated exclusively to the production of glia, and one that generates neurons and/or has the potential to produce neurons.

\section{Possible functions of the TuJ1-positive cells of the proliferative zones}

Presently, we cannot assign an established function to the TuJ1positive cells in the proliferative layers. A remote possibility is that their migration is aborted because they fail to recognize radial glial guides used by other cortical neurons. In other words, they may be "lost cells" that have no function and are probably destined for cell death (Fig. 10).

However, the unique distribution of some of the TuJ1-positive cells suggests that they play a role in the compartmentalization of the developing telencephalon. For example, TuJ1positive cells apparently delineate the border between the proliferative zones of the developing cerebral cortex and striatum in the region of the caudatopallial angle, where an aggregation of TuJ 1-positive cells has been systematically found (Fig. 4). A similar aggregation of calbindin-immunoreactive cells was previously described at this same location at a corresponding developmental period in the rat (Liu and Graybiel, 1992). A defined border between the cortical and striatal ventricular zones could account for the restricted dispersion of cells between these two structures (Fishell et al., 1993). However, the TuJ l-positive cells that arise from the interface between these two structures are directed medially (Fig. 4), in contrast to the restricted longitudinal movement of cells along the striatal and cortical border reported by Fishell et al. (1993). This discrepancy in the direction of migrating cells may arise from the different groups of cells labeled by the DiI technique used by Fishell et al. (1993), which most likely labels progenitor cells, and by the TuJ1 immunochemistry, which labels only postmitotic neurons.

The accumulation of $\mathrm{TuJ} 1$-positive cells at the interface between the ventricular and subventricular zones leads to a speculation of the possible functions that these cells may have in the development of the ventricular zone. The band of TuJ1positive cells along the ventricular zone-subventricular zone border may restrain the to-and-fro movement of the nuclei, characteristic of the proliferating cells of the ventricular zone (see Takahashi et al., 1993). Another role the TuJ1-positive cells may serve, at the border between the ventricular and subventricular zones, is to exclude axons from the ventricular zone (Shoukimas and Hinds, 1978; Edwards et al., 1989). When labeled with Dil, corticothalamic, corticosubcortical, and corticocortical axons never penetrate the ventricular zone of the cerebral cortex and striatum (Menezes and Luskin, unpublished observations). Cortical commissural axons usually run deeper in the cerebral wall than thalamocortical and corticothalamic axons (DeCarlos and O'Leary, 1992; Erzurumlu and Jhaveri, 1992), and their inferior limit coincides with the upper limit of the band of TuJ1-positive cells at the ventricular and subventricular zones (Menezes and Luskin, unpublished observations). These spatial relationships suggest that the $\mathrm{TuJ} 1$-positive cells at the ventricular zone-subventricular zone border may provide a barrier for axonal processes and may also demarcate a path for the elongation of cortical commissural axons.

Finally, TuJ1-positive cells of the proliferative layers may influence the local microenvironment surrounding the cells of the ventricular and subventricular zones. It is possible that the $\mathrm{TuJ} 1$-positive cells can exert an effect on their surrounding cells by the release of neurotransmitters (Van Eden et al., 1989; Cobas et al., 1991; Ma et al., 1992a,b). Furthermore, the TuJ1-positive cells in the proliferative zones may have an effect on the phenotype of subsequently generated cells through cell-to-cell interactions. Precedent for this kind of regulation has been demonstrated during the development of the Drosophila eye (Banerjee and Zipursky, 1990) and the mammalian retina (Reh, 1992). This is further supported by the recent finding that the ventricular zone may be the site where laminar fate is determined in the developing cerebral cortex (McConnell and Kaznowski, 1992).

\section{References}

Altman J, Bayer SA (1990) Horizontal compartmentation in the germinal matrices and intermediate zone of the embryonic rat cerebral cortex. Exp Neurol 107:36-47.

Austin CP, Cepko CL (1990) Cellular migration patterns in the developing mouse cerebral cortex. Development 110:713-732. 
Banerjee A, Roach MC, Treka P, Luduena RS (1990) Increased microtubule assembly in bovine brain tubulin lacking the type III isotype of $\beta$-tubulin. J Biol Chem 265:1794-1799.

Banerjee U, Zipursky SL (1990) The role of cell-cell interaction in the development of the Drosophila visual system. Neuron 4:177-187.

Bayer SA, Altman J (1990) Development of layer I and the subplate in the rat neocortex. Exp Neurol 107:48-62.

Bayer SA, Altman J, Russo RJ, Dai X, Simmons JA (1991) Cell migration in the rat embryonic neocortex. J Comp Neurol 307:499516.

Bennett GS, DiLullo C (1985a) Expression of a neurofilament protein by the precursors of a subpopulation of ventral spinal cord neurons. Dev Biol 107:94-106.

Bennett GS, DiLullo C (1985b) Transient expression of a neurofilament protein by replicating neuroepithelial cells of the embryonic chick brain. Dev Biol 107:107-127.

Boulder Committee (1970) Embryonic vertebrate nervous system: revised terminology. Anat Rec 166:257-262.

Carden MJ, Trojanowski JQ, Schlaepfer WW, Lee VM-Y (1987) Twostage expression of neurofilament polypeptides during rat neurogenesis with early establishment of adult phosphorylation patterns. J Neurosci 7:3489-3504.

Caviness VS (1982) Neocortical histogenesis in normal and reeler mice: a developmental study based upon $\left[{ }^{3} \mathrm{H}\right]$ thymidine autoradiography. Dev Brain Res 4:293-302.

Chronwall B, Wolff JR (1980) Prenatal and postnatal development of GABA-accumulating cells in the occipital neocortex of rat. J Comp Neurol 190:187-208.

Chun JJM, Shatz CJ (1989) The earliest-generated neurons of the cat cerebral cortex: characterization by MAP2 and neurotransmitter immunohistochemistry during fetal life. J Neurosci 9:1648-1667.

Cobas A, Fairén A, Alvarez-Bolado G, Sánchez MP (1991) Prenatal development of the intrinsic neurons of the rat neocortex: a comparative study of the distribution of GABA-immunoreactive cells and the GABAa receptor. Neuroscience 40:375-397.

Crandall JE, Caviness VS (1984) Axon strata of the cerebral wall in embryonic mice. Dev Brain Res 14:185-195.

Crandall JE, Jacobson M, Kosik KS (1986) Ontogenesis of microtubule-associated protein 2 (MAP2) in embryonic mouse cortex. Dev Brain Res 28:127-133.

De Carlos JA, O'Leary DDM (1992) Growth and targeting of subplate axons and establishment of major cortical pathways. J Neurosci 12: 1194-1211.

Del Rio JA, Soriano E, Ferrer I (1992) Development of GABA-immunoreactivity in the neocortex of the mouse. J Comp Neurol 326: 501-526.

Easter SS Jr, Ross LS, Frankfurter A (1993) Initial tract formation in the mouse brain. J Neurosci 13:285-299.

Edwards MA, Crandall JE, Wood JN, Tanaka H, Yamamoto M (1989) Early axonal differentiation in the mouse CNS delineated by an antibody recognizing extracted neurofilaments. Dev Brain Res 49:185204.

Erzurumlu RS, Jhaveri S (1992) Emergence of connectivity in the embryonic rat parietal cortex. Cereb Cortex 2:336-352.

Ferreira A, Caceres A (1992) Expression of the class III $\beta$-tubulin isotype in developing neurons in culture. J Neurosci Res 32:516-529.

Fishell G, Mason CA, Hatten ME (1993) Dispersion of neural progenitors within the germinal zones of the forebrain. Nature 362:636638.

Fujita S (1963) The matrix cell and cytogenesis in the developing central nervous system. J Comp Neurol 120:37-42.

Gressens P, Gofflot F, Van Maele-Fabry G, Misson Jean-P, Gadisseux Jean-F, Evrard P, Picard JJ (1992) Early neurogenesis and teratogenesis in whole mouse embryo cultures. Histochemical, immunocytological and ultrastructural study of the premigratory neuronalglial units in normal mouse embryo and in mouse embryos influenced by cocaine and retinoic acid. J Neuropathol Exp Neurol 51:206-219.

Grove EA, Williams BP, Li SQ, Hajihosseini M, Friedrich A, Price J (1993) Multiple restricted lineages in the embryonic cerebral cortex. Development 117:553-561.

Hajós F, Zilles K, Gallatz K (1990) Vasoactive intestinal polypeptide (VIP) containing cells in the developing rat occipital hemisphere. Anat Embryol (Berl) 182:69-78.

Hamre KM, Cassell MD, West JR (1989) The development of laminar staining for neuron-specific enolase in the rat somatosensory cortex. Dev Brain Res 46:213-220.
Hendry SHC, Bhandari MA (1992) Neuronal organization and plasticity in the adult monkey visual cortex: immunoreactivity for microtubule-associated protein 2 . Vis Neurosci 9:445-459.

Hinds JW, Ruffett TL (1971) Cell proliferation in the neural tube: an electron microscopic and Golgi analysis in the mouse cerebral vesicle. Z Zellforsch 115:226-264.

Johnson GVW, Jope RS (1992) The role of microtubule-associated protein 2 (MAP-2) in neuronal growth, plasticity, and degeneration. J Neurosci Res 33:505-512.

Joshi HC, Cleveland DW (1989) Differential utilization of $\beta$-tubulin isotypes in differentiating neurites. J Cell Biol 109:663-673.

Kaplan MP, Chin SSM, Fliegner KH, Liem RKH (1990) $\alpha$-Internexin, a novel neuronal intermediate filament protein, precedes the low molecular weight neurofilament protein (NF-L) in the developing rat brain. J Neurosci 10:2735-2748.

Lee MK, Rebhun LI, Frankfurter A (1990a) Posttranslational modification of class III $\beta$-tubulin. Proc Natl Acad Sci USA 87:7195-7199.

Lee MK, Tuttle JB, Rebhun LL, Cleveland DW, Frankfurter A (1990b) The expression and posttranslational modification of a neuron-specific $\beta$-tubulin isotype during chick embryogenesis. Cell Motil Cytoskel 17:118-132.

Levitt P, Cooper ML, Rakic P (1981) Coexistence of neuronal and glial precursors cells in the cerebral ventricular zone of the fetal monkey: an ultrastructural immunoperoxidase analysis. J Neurosci 1:2739.

Levitt P, Cooper ML, Rakic P (1983) Early divergence and changing proportions of neuronal and glial precursors cells in the primate cerebral ventricular zone. Dev Biol 96:472-484.

Liu F-C, Graybiel AM (1992) Transient calbindin-D28K-positive systems in the telencephalon: ganglionic eminence, developing striatum, and cerebral cortex. J Neurosci 12:674-690.

Luskin MB (1993) Restricted proliferation and migration of postnatally generated neurons derived from the forebrain subventricular zone. Neuron 11:173-189.

Luskin MB, Shatz CJ (1985) Studies of the earliest generated cells of the cat's visual cortex: cogeneration of subplate and marginal zones. J Neurosci 5:1062-1075.

Luskin MB, Pearlman AL, Sanes JR (1988) Cell lineage in the cercbral cortex of the mouse studied in vivo and in vitro with a recombinant retrovirus. Neuron 1:635-647.

Luskin MB, Parnavelas JG, Barfield JA (1993) Neurons, astrocytes and oligodendrocytes of the rat cerebral cortex originate from separate progenitor cells: an ultrastructural analysis of clonally related cells. J Neurosci 13:1730-1750.

Ma W, Behar T, Maric D, Maric I, Barker JL (1992a) Neuroepithelial cells in the rat spinal cord express glutamate decarboxylase immunoreactivity in vivo and in vitro. J Comp Neurol 325:257-270.

Ma W, Behar T, Barker JL (1992b) Transient expression of GABA immunoreactivity in the developing rat spinal cord. J Comp Neurol 325:271-290.

Mares V, Bruckner JG (1978) Postnatal formation of non-neuronal cells in the rat occipital cerebrum: an autoradiographic study of the time and space pattern of cell division. J Comp Neurol 177:519-528.

McConnell S (1988) Development and decision making in the mammalian cerebral cortex. Brain Res Rev 13:1-23.

McConnell SK (1991) The generation of neuronal diversity in the central nervous system. Annu Rev Neurosci 14:269-300.

McConnell SK, Kaznowski CE (1991) Cell cycle dependence of laminar determination in the developing neocortex. Science 254:282285.

Meller K, Tetzlaff W (1975) Neuronal migration during the early development of the cerebral cortex. A scanning electron microscopic study. Cell Tissue Res 163:313-325.

Meller K, Breipohl W, Glees P (1966) Early cytological differentiation in the cerebral hemisphere of mice. An electron microscopical study. Z Zellforsch 72:525-533.

Miller MW (1988) Development of projection and local circuit neurons in the neocortex. In: Cerebral cortex, Vol 7, Development and maturation of cerebral cortex (Peters A, Jones EG, eds), pp 133-175. New York: Plenum.

Miller MW, Nowakowski RS (1988) Use of bromodeoxyuridine-immunohistochemistry to examine the proliferation, migration and time of origin of the cells in the central nervous system. Brain Res 457: 44-52.

MissonJ-P,AustinCP, TakahashiT, CepkoCL, Caviness VSJr (1991a)The 
alignment of migrating neural cells in relation to the murine pallial radial glial fiber system. Cereb Cortex 1:221-229.

Misson J-P, Takahashi T, Caviness VS Jr (1991b) Ontogeny of radial and other astroglial cells in the murine cerebral cortex. Glia 4:138148.

Mitchison T, Kirschner M (1988) Cytoskeletal dynamics and nerve growth. Neuron 1:761-772.

Moody SA, Quigg MS, Frankfurter A (1989) Development of the peripheral trigeminal system in the chick revealed by an isotypespecific anti-beta-tubulin monoclonal antibody. J Comp Neurol 279: 567-580.

O'Rourke NA, Dailey ME, Smith SJ, McConnell SK (1992) Diverse migratory pathways in the developing cerebral cortex. Science 258: 299-302.

Parnavelas JG, Papadopoulos GC, Cavanagh ME (1988) Changes in neurotransmitters during development. In: Cercbral cortcx, Vol 7, Development and maturation of cerebral cortex (Peters A, Jones EG, eds), pp 177-209. New York: Plenum.

Parnavelas JG, Barfield JA, Franke E, Luskin MB (1991) Separate progenitor cells give rise to pyramidal and nonpyramidal neurons in the rat telencephalon. Cereb Cortex 1:463-468.

Privat A (1975) Postnatal gliogenesis in the mammalian brain. Int Rev Cytol 40:281-323.

Rakic $P$ (1972) Mode of cell migration to the superficial layers of fetal monkey neocortex. J Comp Neurol 145:61-84.

Reh TA (1992) Cellular interactions determine neuronal phenotypes in rodent retinal cultures. $J$ Neurobiol 23:1067-1083.

Reynolds BA, Weiss S (1992) Generation of neurons and astrocytes from isolated cells of the adult mammalian central nervous system. Scicncc 255:1707-1710.

Riederer B, Matus A (1985) Differential expression of distinct microtubule-associated proteins during brain development. Proc Natl Acad Sci USA 82:6006-6009.

Schambra UB, Sulik KK, Petrusz P, Lauder JM (1989) Ontogeny of cholinergic neurons in the mouse forebrain. J Comp Neurol 288:101122.

Schmechel DE, Marangos PJ (1983) Neuron-specific enolase (NSE): specific cellular and functional marker for neurons and neuroendocrine cells. In: Current methods in cellular neurobiology, Vol I, Anatomical techniques (Barker JL, McKelvy JF, eds), pp 1-62. New York: Wiley.

Schmechel DE, Rakic P (1979) A Golgi study of radial glial cells in the developing monkey telencephalon: morphogenesis and transformation into astrocytcs. Anat Embryol (Berl) 156:115-152.

Schwartz ML, Meinecke DL (1992) Early expression of GABA-containing neurons in the prefrontal and visual cortices of rhesus monkeys. Cereb Cortex 2:16-37.

Seki T, Arai Y (1991) Expression of highly polysialylated NCAM in the neocortex and piriform cortex of the developing and adult rat. Anat Embryol (Berl) 184:395-401.

Shatz CJ, Chun JJ, Luskin MB (1988) The role of the subplate in the development of the mammalian telencephalon. In: Cerebral cortex,
Vol 7, Development and maturation of cerebral cortex (Peters A, Joncs EG, cds), pp 35-58. Ncw York: Plenum.

Shoukimas GM, Hinds JW (1978) The development of the cerebral cortex in the embryonic mouse: an electron microscopic serial section analysis. J Comp Neurol 179:795-830.

Silverman WF (1992) Temporal and compartmental restriction of neuron-specific enolase expression in the rat mesostriatal system. Dev Brain Res 69:31-39.

Smart IHM, McSherry GM (1982) Growth patterns in the lateral wall of the mouse telencephalon. II. Histological changes during and subsequent to the period of isocortical neuron production. J Anat 134: $415-442$.

Smart IHM, Sturrock (1979) Ontogeny of the neostriatum. In: The neostriatum (Divak I, Oberg RGE, eds), pp 127-146. New York: Pergamon.

Sullivan KF (1988) Structure and utilization of tubulin isotypes. Annu Rev Cell Biol 4:687-716.

Takahashi T, Nowakowski RS, Caviness VS Jr (1992) BUdR as an S-phase marker for quantitative studies of cytokinetic behavior in the murine cerebral ventricular zone. J Neurocytol 21:185-187.

Takahashi T, Nowakowski RS, Caviness VS Jr (1993) Cell cycle parameters and patterns of nuclear movement in the neocortical proliferative zone of the fetal mouse. J Neurosci 13:820-833.

Tan S-S, Breen S (1993) Radial mosaicism and tangential cell dispersion both contribute to mouse neocortical development. Nature 362:638-640.

Tapscott SJ, Bennett GS, Holtzer H (1981) Neuronal precursor cells in the chick neural tube express neurofilament proteins. Nature 292: 836-838.

Tohyama T, Lee VM-Y, Rorke LB, Trojanowski JQ (1991) Molecular milestones that signal axonal maturation and the commitment of human spinal cord precursor cells to the neuronal or glial phenotype in development. J Comp Neurol 310:285-299.

Tucker RP, Binder LI, Matus AI (1988) Neuronal microtubule-associated proteins in the embryonic avian spinal cord. J Comp Neurol $271: 44-55$

Van Eden CG, Mrzljak L, Voorn P, Uylings HBM (1989) Prenatal development of GABA-ergic neurons in the cortex of the rat. J Comp Neurol 289:213-227.

Walsh C, Cepko CL (1992) Widespread dispersion of neuronal clones across functional regions of the cerebral cortex. Science 255:434-440.

Walsh C, Cepko CL (1993) Clonal dispersion in proliferative layers of developing cerebral cortex. Nature 362:632-635.

Wood JG, Martin S, Price DJ (1992) Evidence that the earliest generated cells of the murine cerebral cortex form a transient population in the subplate and marginal zone. Dev Brain Res 66:137-140.

Yan XX, Zheng DS, Garey LJ (1992) Prenatal development of GABAimmunoreactive neurons in the human striate cortex. Dev Brain Res 65:191-204. 